\title{
The Platonic soul, from the Early Academy to the first century CE
}

\author{
Jan Opsomer, University of Leuven (Internal Research Funds) ${ }^{1}$
}

\section{Plutarch and Timaeus $35^{\mathrm{a}}$}

For the modern reader, Timaeus 35a counts among the more abstruse passages in Plato's dialogues. But for ancient Platonists, too, it was considered to be obscure, yet also exerted an enduring fascination and was believed to contain the key to understanding Plato's concept of the soul. It indeed provides a technical description of the composition and nature of the world soul and can therefore be used better to understand the (rational) human soul, which was held to be structured analogously. Plutarch of Chaeronea is the author of an exegetical work dedicated to this passage. ${ }^{2}$ Even though it is the oldest extensive treatment to have come down to us, there is strong evidence, as I hope to show, for an older exegetical tradition, going back to debates in the Early Academy. This exegetical tradition may not have been continuous, but there are traces of it even in the Hellenistic era. In this contribution I offer a reconstruction of the tradition preceding Plutarch. ${ }^{3}$ Not only will this allow us a better understanding of Plutarch's own project, but it will also shed some light on some relatively unknown chapters in the history of the interpretation of Plato and on some other issues that are better known, but not fully understood, as for instance Xenocrates' and Speusippus' definitions of the soul.

As Plutarch reads the passage, Plato specifies four 'ingredients' or constituents:

(a) 'indivisible and always changeless being' (short: Indivisible Being);

(b) '[being] that becomes divisible in the presence of - or 'around' - bodies' or also

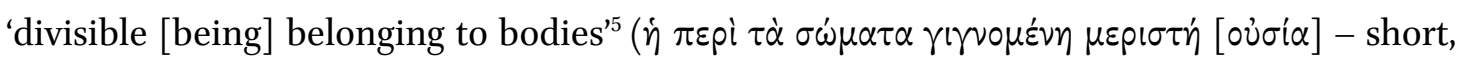
but less accurate: 'Divisible Being');

\footnotetext{
${ }^{1}$ I would like to thank the participants of the Symposium Hellenisticum for their helpful questions and observations, and especially Brad Inwood, David Sedley, James Warren and the anonymous referees for their written remarks, from which I have greatly benefited. I further thank Emidio Spinelli, Francesco Verde, Riccardo Chiaradonna, Thomas Johansen, Eyjólfur Emilsson, and the members of the Centre Léon Robin for their comments.

${ }^{2}$ More precisely to the consecutive passages Tim. 35a1-b4 and 35b4-36b5.

${ }^{3}$ Some later interpretations are examined in Phillips (2002).

${ }^{4}$ See also Sext. Emp. Pyrrh. Hyp. 3.189.
} 
(c) 'the nature of the Same';

(d) 'the nature of the Different.'

Understanding the passage, according to Plutarch, involves knowing what entities or powers are denoted by these expressions and what role they play once they have entered into the blend. A further concerns the steps of the blending process. Plutarch thinks there are two: first the demiurge mixes (a) with (b); subsequently he adds (c) and (d) to the original mixture. This aspect of his interpretation is not remarkable: most of his predecessors ${ }^{6}$ appear to have envisaged the mixing process in the same manner, as we shall see. The identification of the different entities was much more controversial. On Plutarch's view:

(a) Indivisible Being is god, that is, the demiurge, or reason.

(b) Divisible Being is 'soul itself', that is the original, irrational soul, the principle of disorderly motion.

(c-d) The Same and the Different are higher metaphysical principles, which derive from the even higher principles, the One and the Dyad. Probably (a) and (b) are held to derive themselves from (c) and (d), respectively.

Plutarch's solution is original especially with respect to his identification of (b), which involves the idea that the original soul is a principle of irrationality, that is, a principle of evil. He moreover insists on the novelty of the view that the blending of the soul by the demiurge is to be understood as an actual event at the beginning of time. The role Plutarch attributes to these constituents ${ }^{7}$ is much less original: both in the cosmic and the human soul their influence can be observed in motions and cognitions. The dualistic character and provenance of the ingredients show itself in the antagonism of good and evil, order and disorder. The presence of the original, disorderly soul

\footnotetext{
${ }^{5}$ Of little use here is A.E. Taylor's translation 'transient and divisible corporeal being'. Taylor argues that $\pi \varepsilon p i ́$ + acc. is here a mere equivalent of a genitive (Taylor (1928) 108). The ancients clearly disagree, because they unanimously distinguish this 'divisible being' from the being of bodies. See, e.g., Calcidius' translation, 27.8-9 Waszink: alia, quae inseparabilis corporum comes per eadem corpora scindere se putatur.

${ }^{6}$ For some exceptions, see infra, n. 108 .

${ }^{7}$ For an accurate understanding of Plutarch, and possibly of some of the other philosophers discussed here (although in their case the details of the theory are mostly unclear) it is useful to distinguish between these entities understood as 'ingredients', considered as independently existing things, and the same entities as constituents, that is, their nature and role in the mixture.
} 
within the cosmic soul and especially in the human soul can be felt in their erratic motions and doxastic cognitions. The original, disorderly soul is Plutarch's principle of badness.

What has been ignored so far and what I want to discuss here, is the fact that, regarding these questions and answers, Plutarch has inherited several assumptions from the earlier Platonic tradition:

- the firm conviction that Tim. 35a-b is the key passage for understanding the Platonic soul;

- the view that cognition and motion are the primary functions of the soul, or at any rate among the primary functions of the soul.

- the understanding of the mixing process as a two-step process starting from four ingredients: it involves first the mixture of (a) and (b) and then the admixture of (c) and (d) to this first blend. This is different from our standard reading of Tim. 35a, which follows Proclus. The 'modern' reading (canonised by Grube (1932)) requires that one read $\alpha \dot{\tau} \tau \hat{\omega} \nu$ at Tim. 35a6, whereas Plutarch and several of his predecessors discussed in this paper, probably read $\alpha \dot{\tau} \tau \eta^{8}{ }^{8}$ On the 'modern' understanding six ingredients enter into the mixture: in a first step, divisible being is mixed with indivisible being; divisible sameness with indivisible sameness; divisible difference with indivisible difference. The results of these first mixtures are intermediate forms of being, sameness and difference. In a second step these intermediate forms are joined together so as to form the cosmic soul.

The authors that I shall discuss in this paper start from roughly the same assumptions as those I have just outlined for Plutarch. Besides the kinetic and/or cognitive functions they attribute to the constituents some authors also give them what I shall call an ontological function, which has to do with the spatial dimensionality of the soul or with the soul as the principle of three-dimensional extension.

\section{Ar. $D A$ I.2, 404b16-30}

The earliest interpretations of Plato's account are found in an obscure passage from De anima I.2, which begins with an patent reference to Tim. 35a and continues with a discussion of some

\footnotetext{
${ }^{8}$ Cf. Opsomer (2004) 140-41.
} 
apparently related doctrines, the authorship of which Aristotle does not specify. These views are reported in a highly condensed form and are difficult to understand.

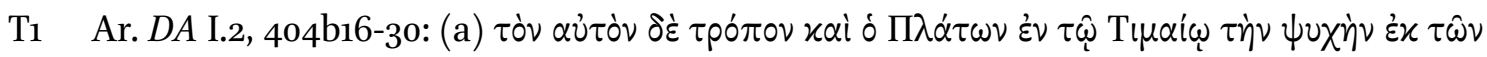

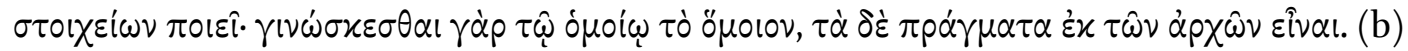

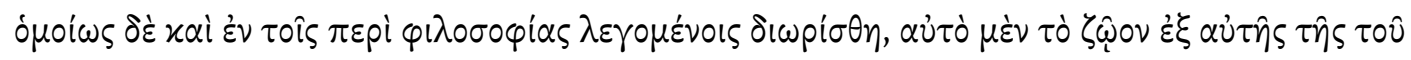

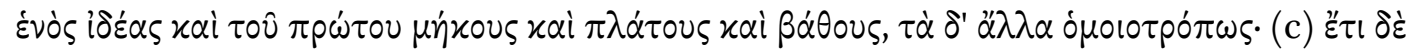

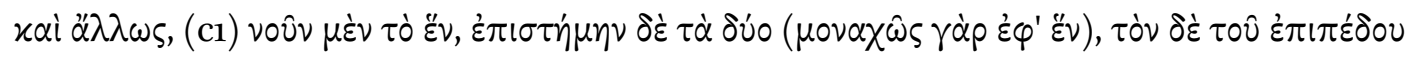

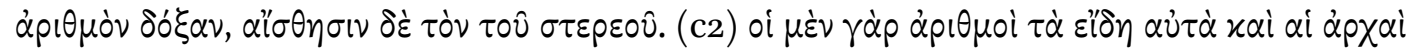

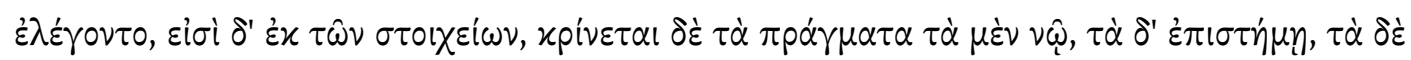

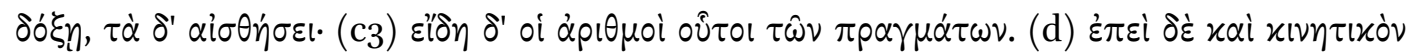

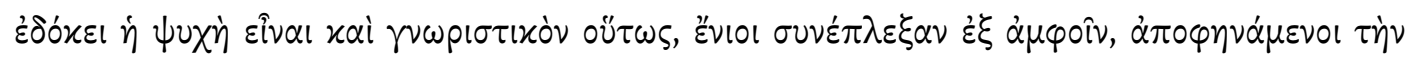

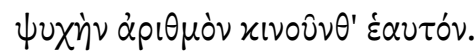

(a) In the same manner [sc. as Empedocles] Plato in the Timaeus constructs the soul from the elements; for like, he holds, is known by like, and things are formed out of the principles. (b) Similarly also in the lectures 'On Philosophy' it was determined that the Animal-itself is compounded of the Form itself of the One together with the primary length, breadth, and depth, the other [things/animals] being similarly constituted. (c) And in yet another way: (c1) One is intelligence, Two is knowledge (because it goes to one point in a single way), the number of the plane is opinion, the number of the solid sensation; (c2) for the numbers were commonly identified with the Forms themselves or the principles, and consist of the elements; and some things are apprehended by intelligence, others by knowledge, others by opinion, others by sensation; (c3) and these same numbers are the forms of things. (d) And since the soul was deemed to be originative of both motion and, in this way, of cognition, some thinkers, twining it together from both, have declared the soul to be a number moving itself.

In (a) Aristotle introduces Plato through a comparison with Empedocles: both think the soul is cognitive and therefore needs to be compounded of the same principles that also constitute the things cognised. The fact that these principles are obviously four in number - something Aristotle does not state - explains the connection with sections (b) and (c): in (b) 'one' is followed by the three spatial dimensions that are somehow constitutive of the Animal-itself, and (c) contains a 
number of reflections on a list of four cognitive faculties or states. Whereas (a) and (c) evidently, and (b) presumably, relate to the cognitive aspect of the soul, whose four constituents are connected to the objects of cognition, the definition in (d), attributed to 'some', is said to unite the cognitive with the kinetic aspect and make the former depend on the latter. Section (a) alone is unambiguously connected to a Platonic text. The way the text develops suggests no other author for $(b)^{9}$ and (c). Iamblichus accordingly understands the doctrine reported in (b-c), too, as Plato's (cf. infra, p. 13). Yet this is not what all commentators think. M. Isnardi Parente argues that (b) and (c) present the views of Speusippus. ${ }^{10}$ This view has been combatted by L. Tarán, ${ }^{\text {" }}$ following H. Cherniss, ${ }^{12}$ who had asserted that "the passage refers to Xenocrates and no one else." As to (d), several ancient sources ascribe its definition to Xenocrates, but the doxographic tradition attributes it to both Pythagoras and Xenocrates. Without taking a stance in the debates regarding the authorship of these doctrines, ${ }^{13}$ one can safely say that the whole passage exudes a strong Pythagorean flavour, especially regarding the idea that things are composed of numbers; ${ }^{14}$ it is certainly no coincidence that the Timaeus was perceived as a Pythagoreanising dialogue. This explains why in the later tradition these doctrines could appeal to certain Platonists, and why even an attribution of the definition in (d) to Pythagoras could be attractive to some.

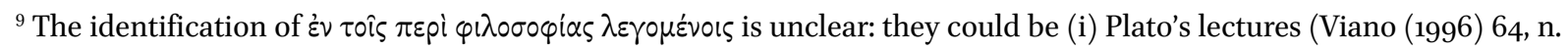
30. See also Krämer (1964) 161, 202), (ii) lectures by a student of Plato, for instance Xenocrates (as claimed by Them. in $D A$ 11.18-12.33 - see Brisson (2000a) 91-98; Finamore and Dillon (2002) 85, n. 11.), or also (iii) his own lost work On Philosophy (Pseudo-Simpl., in DA 28.7-9 and Philop. in DA 75.34-76.1 identify this work with On the good, in which Aristotle supposedly reported non-written doctrines of his master.) Only in case the reference is to the work of one of Plato's students, which Aristotle's intended audience would have known, (b) would mark a shift to doctrines, or interpretations, that are no longer Plato's own.

${ }^{10}$ Isnardi Parente (1971); Isnardi Parente and Dorandi (2012) 296. Krämer (1964) 161, 203-7 considers these doctrines to be Plato's own.

${ }^{11}$ Tarán (1981) 459-6o.

${ }^{12}$ Cherniss (1962) 565-79; Cherniss (1959).

${ }^{13}$ Most scholarship on the Old Academy is predicated on the convenient but questionable assumption that each thinker can be connected to no more than one position on any given issue. The evidence presented by Aristotle is perfectly compatible with, and even suggests, a different picture: that of lively debates with participants willing to test different positions. A similar scholarly assumption can be called the original sin of the unwritten doctrines school: the idea that there is one rigid set of doctrines trumping the philosophy in the dialogues. The various definitions of the soul examined in the present contribution may each correspond to a single consistent account attributable to one author, but that does not mean that diverging views outlined here, for instance, in Aristotle's report, could not belong to the same authors.

${ }^{14}$ This would also be confirmed by a passage from Theophrastus, Met. 6a23-b9.
} 
In (a) Aristotle explains the rationale for Plato's account in Tim. 35 a as being the axiom 'like is known by like.' Plato does not explicitly state this principle in this context. ${ }^{15}$ The idea is that the ingredients that enter into the composition are preserved in the blend (they become components of the end product) and permit the soul to know what is out there in the world (including the intelligible) and what is qualitatively like these ingredients. What these components are Aristotle does not here explain.

The mention, in (b), of the Animal-itself recalls Tim. 39e7-40a4. There we read that it comprises four kinds, but the idea that it contains the monad together with the primary length, breadth and depth is not stated (it could have been mentioned by Plato in his lecture, if that is what Aristotle refers to). But why does Aristotle mention the Animal-itself? Does he equate it with the world-soul (mentioned in (a))? That would be remarkable, to say the least. Or does he mean that just as the soul is composed of the elements which it cognises in other things, the intelligible Animal, too, is composed of elements that are also present in other things - possibly the same elements the soul cognises? Maybe Aristotle's reader is supposed to figure out that since the Animal-itself is the model for the cosmos, its constituents will have cosmological analogues. Aristotle specifies the four constituents of the Animal-itself. They are the form of the One followed by the cortège of the three dimensions: line, plane and solid. Reading (c) back into (b) one could plausibly infer that these four, or rather their analogues, are also part and parcel of the soul. If this is the case, we may very well have an interpretation of the Timaeus according to which the four ingredients indivisible being, divisible being, sameness and difference - are identified with the One (indivisible, analogous to an indivisible point), the first length (the dyad, principle of divisibility), $<$ the first $>$ breadth (the triad), and <the first > depth (the tetrad) $\cdot{ }^{16}$ Of course this remains speculative.

What is important for later Platonic concepts of the soul is the fact that the text provides very early authority for the view that unity and the three dimensions are somehow constitutive of the soul. If one reads (b) as pertaining to the paradigm different from - prior to - the soul, the dimensions first originate in the paradigm, but if one understands (b) as already being about soul, it is rather

\footnotetext{
${ }^{15}$ See also $D A$ I.2, 405b13-16.

${ }^{16}$ For the relation between the one and the point, and between the numbers $2-3-4$ and the three spatial dimensions, see Ar. Met. N3, 109ob20-24.
} 
the soul which is the source of the dimensions. Hence either the paradigm or the soul is seen as containing the principles of the three dimensions. ${ }^{17}$ Aristotle indeed speaks of the primary length, breadth and depth. Probably the idea is that at the level of soul the four constituents of the tetraktys appear as point-line-plane-solid. ${ }^{18} \mathrm{We}$ will later see the same conception of the soul as principle of dimensionality in Speusippus and Posidonius. ${ }^{19}$ It is indeed possible that Speusippus is the real author of the doctrine reported in (b). If that is the case, it would lend support to the interpretation of his definition discussed below, the purport of which is not that the soul is threedimensional, but rather that it is the source of the three dimensions, as comprising primary length, breadth and depth.

Section (c) is presented as a different approach to the same issue. In (c1) the numbers are connected to a sequence of cognitive faculties (rather than states): intelligence, knowledge, opinion, and sense-perception. ${ }^{20}$ Moreover the numbers two-three-four are here aligned with the three dimensions (as in b). In (c2) and (c3) the principle 'like is known by like' (from a) is recalled and explained: numbers stand for the forms of cognition and are their principles (c2), and they, or rather their principles or 'elements', ${ }^{21}$ are also (c3) the forms of the things ${ }^{22}$ cognised by the faculties (possibly, as in (b), because they provide the dimensions of sense-perceptible things and analogously constitute the objects of the other cognitive faculties). Aristotle may hint at the idea that the four items from Tim. 35a stem from the Pythagorean principles of number: the odd (the Different), the even (the Same), the limited (indivisible being) and the unlimited (divisible being) ${ }^{23}$ One could also think that in (c2) he is referring to Form-numbers and their constituents (that is, the tetraktys) as defining the cognitive faculties and at the same time (c3) as being the formal causes of things. Be that as it may, important for understanding later developments are the close association of intelligence/intellect with one, ${ }^{24}$ and the fact that perception comes fourth. ${ }^{25}$

\footnotetext{
${ }^{17}$ Ross (1961) 179 .

${ }^{18}$ Dillon (2003) 23, 109, n. 63. See also Gaiser (1998) 46-47.

${ }^{19}$ Leg. X, 896C5-D3 could be read as lending support to this idea, although Plato may be saying no more than that soul is prior to body, which happens to have three dimensions (yet one may ask why Plato would like to mention dimensions at all, if not in order to suggest that soul is anterior to three-dimensional extension).

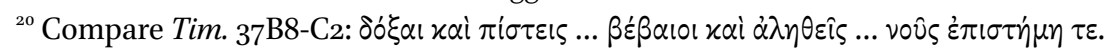

${ }^{21}$ See also Met. A2, 985b32-986a2.

${ }^{22}$ Met. A2, 987a17-22.

${ }^{23}$ Met. A2, 986a17-19.

${ }^{24}$ Cf. Krämer (2014) 145, n. 84.
} 
This passage also sheds light on the idea, found in later texts, that soul is connected with the number four: it has all cognitive faculties, down to perception. ${ }^{26}$

Section (d) differs from (a-c) not only because Aristotle explicitly connects it to other thinkers, but also because the definition accounts not only for cognition, but also for motion. ${ }^{27}$ Throughout his doxography, Aristotle distinguishes between thinkers who highlight either the cognitive or the kinetic role of the soul, or both. However, in the brief account of the Platonic theories that we have just examined, a third aspect came to the fore: the connection between the soul and spatial extension. These three aspects will remain important in the Platonic reception of these Early Academic conceptions.

Aristotle's account testifies to discussions in the Early Academy. The views he presumably wants to attribute to Plato in (a-c) may indeed have been Plato's, that is, to his own participation in oral debates. Sections (b) and certainly (c) go beyond the text of the Timaeus and could just as well be the result of interpretations or new doctrinal efforts on the part of Plato's followers, who may have or may not have presented these as Plato's own.

Starting from Tim. 35a and the debates in the early Academy to which Aristotle bears witness, and to all likelihood also through his account, an exegetic tradition was born that looked at this passage and the texts surrounding it for an answer to the question what the soul essentially is. More in particular, the passage should tell us which constituents of the soul or which principles producing its essence explain its functions. Aristotle's account of his predecessors is structured around the question whether they want to explain either the cognitive or the motive powers of the soul. The Platonist passage of the doxography, however, shows a third issue at play, namely the function that I have termed 'ontological' and that has to do with the soul as the source, or possibly also the first physical manifestation, of the three spatial dimensions. Our main later sources for the exegetical tradition will be Plutarch, Iamblichus, the pseudo-Pythagorean corpus, and the doxographic

\footnotetext{
${ }^{25}$ Possibly the enigmatic remark in Plat. Leg. X, 894A1-5 is related to this idea.

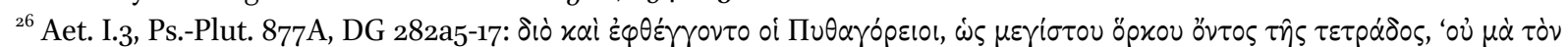

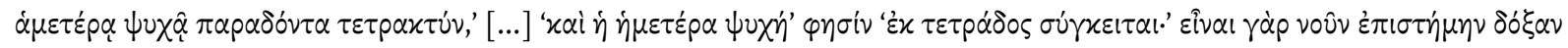

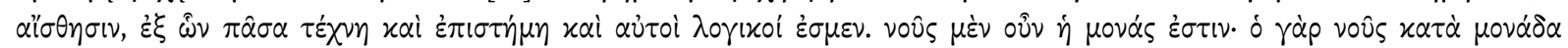
$\theta \varepsilon \omega p \varepsilon i \tau \alpha l, x \tau \lambda$. See also Ps.-Iambl. Theol. Arith. 30.2-9 (a passage stemming from Anatolius); Sext. Emp. AM 4.6-9.

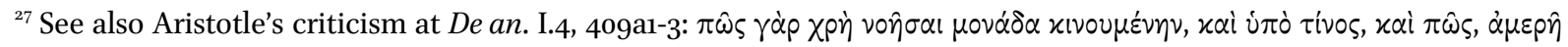

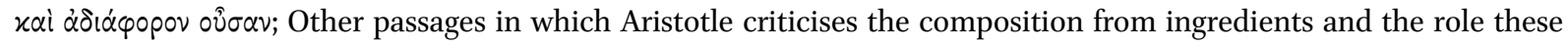
are supposed to play in cognitions are $D A \mathrm{I}_{3}, 406 \mathrm{~b}_{2} 6-407 \mathrm{a} 5$ and 407a17-21.
} 
tradition. Only with Iamblichus do we find incontrovertible evidence of the Platonic reception of $D A$ I.2 in the discussion of what the soul is and does according to Plato. The older sources that we shall discuss definitely point to interpretations that stand in the same tradition: the philosophical issues that they connect to Tim. 35a are the same. Whether these interpreters knew DA I.2 or had direct access to other texts from the ancient academy is impossible to determine with certainty.

\section{Xenocrates (or Pythagoras?)}

The anonymous definition of the soul as self-moving number cited by Aristotle $(\mathrm{T} 1, \mathrm{~d})$ is featured in Plutarch's treatise on Tim. 35a. Plutarch attributes the definition to Xenocrates ${ }^{28}$ and contrasts it with Crantor's definition (De an. procr. 1012D2-F1): Xenocrates "declares the essence of the soul to

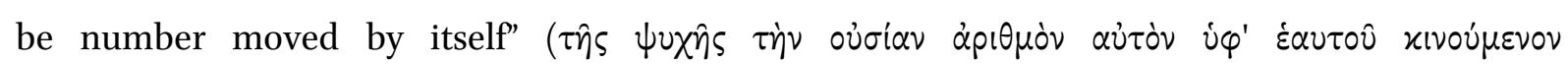
$\dot{\alpha} \pi \circ \varphi \eta \nu \alpha \dot{\mu} \varepsilon v 0 \varsigma)$. What was at best implied by Aristotle now becomes crystal clear: this definition is the result of a specific reading of Tim. 35a. Four ingredients are mixed in two steps: (1) divisible being is mixed with indivisible being; (2) sameness and difference are added to the blend. The mixture of indivisible and divisible being produces number. For number is generated when the one ( $\tau \dot{0} \varepsilon v)$, that is the indivisible, bounds multiplicity, that is the divisible. The divisible is equated with the indefinite dyad, also called the unlimited ( $\left.\dot{\alpha} \pi \varepsilon ı p^{\prime} \alpha\right)$, upon which the one imposes limit ( $\pi \dot{\varepsilon} p \alpha \varsigma)$. Plutarch explains that Zaratas, the teacher of Pythagoras, calls the one the father of number, and the dyad its mother. It is not clear whether Plutarch adds this remark about Zaratas on his own account or whether it was already part of Xenocrates' argument, but it is certainly Xenocrates who is reported to have hold that number becomes soul when active and passive

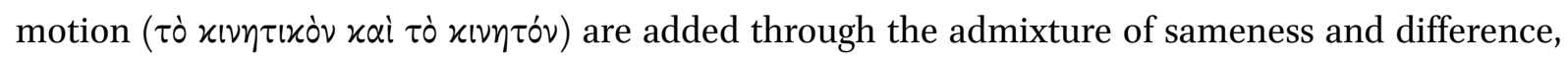
which are the principles of rest and motion, respectively. With respect to both rest and motion

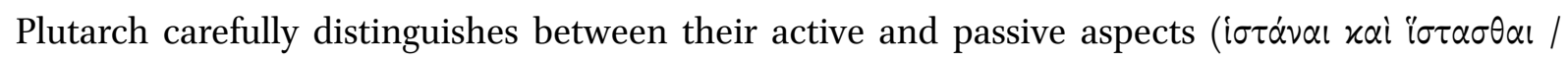

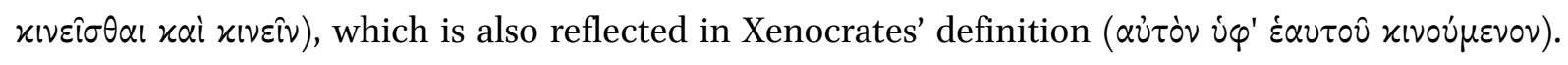
Soul moves itself and is thereby itself in motion and it is able to halt itself and thereby to be at rest. One could even speculate that for Xenocrates the active and passive aspect correspond to

\footnotetext{
${ }^{28}$ See also De an. procr. 1025A6-B9; E9-F1; F6-1026A3.
} 
indivisibility and divisibility, respectively, ${ }^{29}$ which would mean the role of those two ingredients is not limited to the generation of number. I should add that 'number' should probably not be taken in the sense of a simple cardinal number, but rather in the sense of an entity characterised by a more complex arithmetic structure, with numbers determining internal harmonic proportions, in the spirit of Tim. 35b1-36d7.

Contrary to Aristotle, Plutarch presents Xenocrates' concept of the soul primarily under its motive aspect, in combination with an account of the origin of number.$^{30}$ This makes for a nice contrast with Crantor, who "mixes the soul from intelligible nature and from doxastic nature belonging to

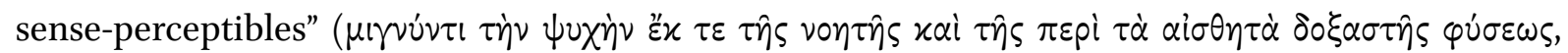
1012D8-9), appealing to these ingredients in order to explain the cognitive function of the soul. Yet later in the text Plutarch criticises Xenocrates' definition for its lack of explanatory power in relation to the soul's cognitive function: neither number (Xenocrates) nor limit (Posidonius) are of any use to explain the cognition of sense-perceptibles (1023D4-7). By this remark he shows himself to be aware of the fact that for Xenocrates, too, the composition of the soul is supposed to account for cognition as well.

The definition of the soul that Plutarch and many others (e.g. Iamblichus ${ }^{31}$ ) attribute to Xenocrates is also quoted in the Placita, but there it is surprisingly ascribed to Pythagoras: "Pythagoras [says the soul is] self-moving number, taking number to stand for intellect." ${ }^{22}$ The two sources for this doxographic report, pseudo-Plutarch and Stobaeus, provide the same text, except for two orthographic variants Then Stobaeus - that is, his source -, but not Pseudo-Plutarch, adds that

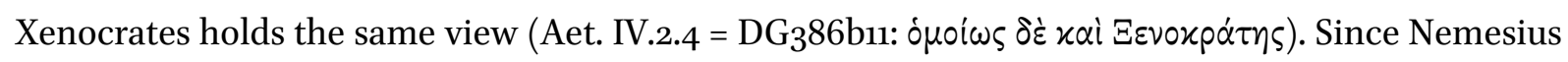
and Theodoretus, who are independent witnesses for Aetius, make the same remark, we may infer that it was already in Aetius..$^{33}$ Aetius' comment about the word 'number' in the definition being

\footnotetext{
${ }^{29}$ Compare Ar. Ph. VI.4, 234b1o; VIII.10, 266a10-11; 267b25-26.

${ }^{30}$ Theophrastus apparently did not have in mind this combination of number with movement when he criticised the Academics at Met. 4a21-b5.

${ }^{31}$ Xenocrates F85-F121 Isnardi Parente; Iambl. De an. ap. Stob. Ecl. I.49, p. 364,9-10 W.

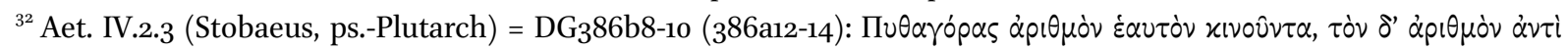
$\tau \circ \hat{v}$ v०טิ $\pi \alpha \rho \alpha \lambda \alpha \mu \beta \alpha \dot{\nu \varepsilon l . ~}$

${ }^{33}$ See the 'revised schema for the transmission' of the doxographical tradition at Mansfeld and Runia (1997) 328 and also id. p. 294. See also Mansfeld and Runia (2009) 140-42, who show that the way these sections on the soul in Aetius are structured strongly suggest a Peripatetic context, and more precisely, in this particular case, an influence of $D e$ anima I.2. See also Viano (1996) 51 and Mansfeld (2016) 311.
} 
equivalent to intellect most probably derives, mediately, from Aristotle $D A$ I.2, 404b16-30, and stems from an attempt to make sense of the view here attributed to Pythagoras and Xenocrates. As we have seen, Aristotle reports that Plato or Platonists identify or at least closely associate intellect with the monad (404b22). A few lines down he quotes, without naming its author, what we take to be Xenocrates' definition (404b29-30). Later on Aristotle alludes to the same definition but substitutes 'monad' for 'number'. ${ }^{34}$ Aetius or, more probably, his source probably took his cue from there and understood the definition of soul as being 'intellect in motion', possibly assuming ${ }^{35}$ that this was Pythagoras' definition. ${ }^{36}$ In this light it is remarkable that, in the Quaestiones Platonicae, VIII, 1007 c5-6, $^{-6}$ Plutarch ascribes the same definition not to Xenocrates, but to 'the ancients'. Possibly Plutarch thought that the definition was not just Xenocrates', but generically Pythagorean and later adopted by Xenocrates. He would then assume that this is a case of Xenocrates Pythagoreanising. This is in line not only with how Iamblichus ${ }^{37}$ treats this doctrine and with the conclusion at which Aetius or his source had arrived, but also with the fact that in De animae procreatione Plutarch implies that Xenocrates associated the interpretation on which the definition is based with Zaratas, the presumed teacher of Pythagoras.

\section{Crantor}

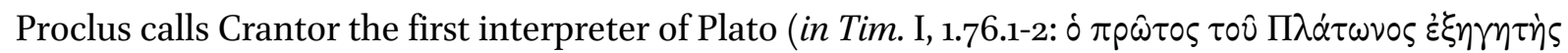

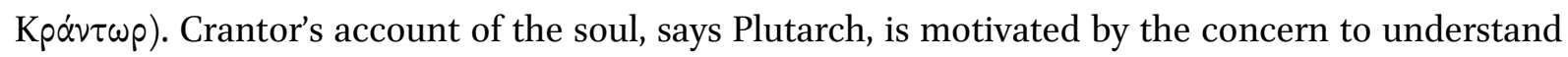
how the soul is able to cognize both sense-perceptibles and intelligibles, forming judgments about

\footnotetext{
${ }^{34}$ De an. I.4, 409a1-3, cf. n. 27.

${ }^{35}$ Finamore and Dillon (2002) 83 submit that Xenocrates himself "made some attempt to father his own doctrine on Pythagoras." While this may be true, it is equally possible that some reader of Aristotle's De anima tried to make sense of the passage and thought the definition was Pythagorean because of the preceding passage in which numbers were given symbolic meanings.

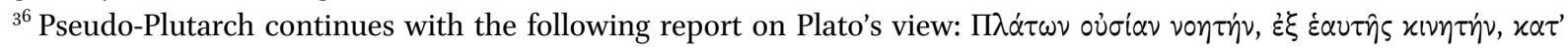

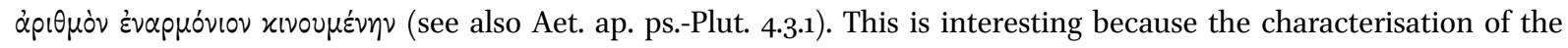
soul as intelligible, which here is merely the opposite of sense-perceptible, is shared by Plutarch. Plato, Leg. 898D9-E2

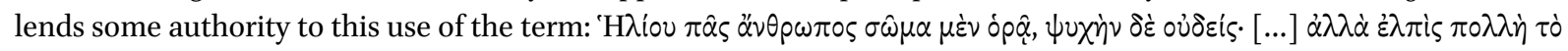

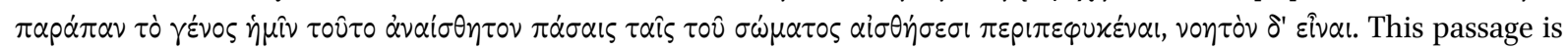
quoted partim by Plut., Quaest. Plat. III, ${ }_{1002} \mathrm{C}_{3}-5$. It is one of the several parallels that show that Plutarch, his sources and the doxographical tradition belong to the same broad intellectual context. Plutarch uses vontós for the entire supersensible realm and anything in it, for instance the soul. See Quaest. Plat. III, ${ }_{1002 C}$, where he justifies this usage of the term by quoting Plato, Leg. $898 \mathrm{E}$.

${ }^{37}$ Iambl. De an. ap. Stob. Ecl. I.49, p. 364,9-10 W. lists Xenocrates in the camp of the Pythagoreans.
} 
their differences and sameness $\left(1012 \mathrm{~F}_{2}-1013 \mathrm{~A} 5\right)$. Based on the same idea that like is known by like, Crantor lets divisible and indivisible being stand for the two realms that the soul is meant to know, and sameness and difference as the tools for discernment in both of these realms and across realms (similarities and differences of sense-perceptibles with one another; of intelligibles with one another; of sense-perceptibles with intelligibles; cf. Tim. 37 3). This is his explanation for the four ingredients in the soul's composition. It should be noted that this is essentially the same explanation as that of Alcinous (Did. 14, 169.16-31 W.-L.). Crantor's influence on this Middle Platonic text is incontestable, even if this influence may have passed through intermediary stages. ${ }^{38}$ Plutarch takes Crantor to understand the blending of ingredients in such a way that the ingredients are preserved in the mixture, which would make him liable to the charge of materialism.

\section{Speusippus}

Two sources from late Antiquity provide additional evidence for early interpretations of Timaeus 35a: Iamblichus De anima (ap. Stob. I,49, 363.26-365.4 W. = F7-8 Martone = F4-5 (Finamore-Dillon / Martone), and Proclus in Tim. III, 2.152.25-154.26. The two accounts are similar in the way in which they organise their material and partly report the same views as representing the different dialectical positions. The most plausible hypothesis is that they depend from the same doxographic source or tradition, ${ }^{39}$ which used a diaphonic organisation (Plutarch's construal of the opposition Xenocrates-Crantor may very well derive from a similar diaphonic doxography $\left.{ }^{40}\right)$. In his doxography on the interpretation of Indivisible and Divisible Being, Proclus distinguishes three groups among the pre-Plotinian interpreters (in Tim. III, 2.153.16-154.1): (1) mathematical interpretations, divided into (1a) arithmetic and ( $1 \mathrm{~b})$ geometric interpretations, and (2) physical

\footnotetext{
${ }^{38}$ Starting from the assumption that Eudorus was Plutarch's source on the Old Academy, Dillon (1993) 121-22 argues that Alcinous' account goes back to Eudorus, whom he presumes to have followed Crantor. Alcinous accessed this information through the intermediary of Arius Didymus. There is indeed a literal parallel between 'Didymus' quoted by Eusebius (PE 11.23.2-6) and a substantial section of Alcinous chapter 12, but Dillon like many others believe the presence of Didymus extends beyond this chapter. Göransson (1995) 182-202 argues that Didymus is not the source for Alcinous, but rather that the excerpt preserved by Eusebius is on the contrary based on this text. For a balanced account of this thorny issue, see Mansfeld and Runia (1997) 238-44.

${ }^{39}$ See also Mansfeld (1990) 3076. See also p. 3084-3085 on the diaphonic organisation of several doxographies.

${ }^{40}$ Plutarch's direct source is often claimed to be Eudorus, because Plutarch cites him as commenting upon Xenocrates and Crantor's rejection of the soul's temporal origin. Cf., e.g., Helmer (1937) 13, n. 18; Cherniss (1976) 170-71 n. c; 165, n. c.
} 
interpretations. The arithmetic interpretation considers the soul as number, created from the monad and the indefinite dyad. Its advocates are "the followers of Aristander, Numenius and a great many other commentators". The geometric interpretation is that of Severus and considers the geometric substance of the soul to be constituted by point and extension. Plutarch and Atticus are quoted as proponents of the physical interpretation, as they consider the irrational soul (Divisible Being) to be a physical entity that exists before the rational soul. According to Proclus, they blend the irrational soul with the divine soul (Indivisible Being), the result of this mixture being the rational soul. Whereas the mathematical interpretations make these constituents or principles of soul intermediate between the physical and the transcendent realm, and the physical interpretation even makes one of them belong to nature, the loftier Neoplatonic interpretations situate them among the principles that transcend nature (in Tim. III, 2.154.1-9). ${ }^{41}$ Proclus' account of the arithmetic interpretation would seem to agree with the Xenocratean definition, whereas his report on the geometric interpretation would also fit the view discussed in $\mathrm{T} 1, \mathrm{~b}$, as well as the Speusippean definition as reported by Iamblichus. I refrain from discussing the views of those who fall outside the chronological scope of this contribution.

According to Iamblichus' classification, ${ }^{42}$ an important group of interpreters considers the essence of the soul to be mathematical. The mathematical interpretation consists of two subgroups: the numerical and the geometric interpretation. Among those who discuss the soul in numerical terms he lists "some Pythagoreans who connect soul to number simpliciter"; Xenocrates with his definition of soul as self-moved number; "Moderatus the Pythagorean" who thinks the soul is number comprising ratios; "Hippasos the acousmatic Pythagorean" who speaks of "[number as] the criterial instrument of the world-creating god"; and finally Plato's view as reported by Aristotle (cf. T1, a). The proponents of the geometric interpretation are philosophers who hold the soul to be essentially either the shape as extended throughout, that is everything within its borders, or as the borders or limits themselves: Severus advocates the first view; Speusippus, the second.$^{43} \mathrm{~A}$ totally different group considers the soul to be harmony (here Moderatus is cited once more).

\footnotetext{
${ }^{41}$ For Aristander, Severus, and Numenius, see Boys-Stones (2018) 229-30.

${ }^{42}$ Iambl. De an. 4 (Finamore-Dillon) / 7 (Martone), ap. Stob. Ecl. I.49, p. 363.26-364.18 Wachsmuth.

${ }^{43}$ Pace Finamore and Dillon (2002) 80. This way of distinguishing the position of Severus from that of Speusippus is confirmed by Procl. in Tim. III, 2.152.21-30. Festugière (1990) 180, n. 1, followed by Martone (2014) 102, understands ह่v
} 


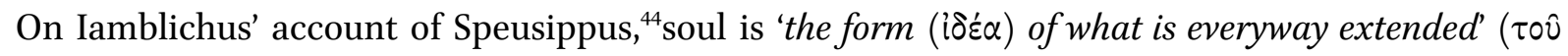
$\pi \alpha \dot{\nu} \tau \eta \delta(\alpha \sigma \tau \alpha \tau \odot \hat{v}) .{ }^{45}$ As far as I know, no modern interpreter has connected this definition with Tim. 35a. Yet on closer inspection several elements speak in favour of the association of the definition with this precise passage. Not only is its conceptual framework quite close to sections (b-c) of Aristotle's account ( $\mathrm{T} 1)$, but also the comparison with Posidonius, who, as we shall see, takes over this definition, shows that Tim. 35a indeed provides the original context. And finally it will be possible to detect in the definition two of the four components mentioned by Plato.

What is intriguing about the definition 'form (idea, rational structure) of what is extended in all directions', is that it is not obviously the definition of anything psychic. One would be forgiven for thinking it perfectly applies to the form of any hylomorphic material body. Yet the definition does not state that that which is defined has three-dimensional extension, but rather that it provides the idea grounding the three spatial dimensions. Speusippus does not accept Plato's Forms; but it is unlikely that idea here means 'Platonic Form'. It should rather be taken (as later in Posidonius' definition), as 'form' or 'formal principle', in accordance with Plato's own usage at Tim. 35a7 (Eis $\mu(\alpha \nu \ldots i \delta \dot{\varepsilon} \alpha \nu)$. One could object that Speusippus may merely be interpreting Plato, without agreeing with him, so that idea in the definition could still stand for 'Platonic Form'. There is, however, no need to give idea this strong metaphysical meaning. There is no evidence pointing in the direction of Speusippus' using the definition in this sense. H. Cherniss makes the observation that the definition looks like an attempt to defend Plato's concept of the soul as it appears in the

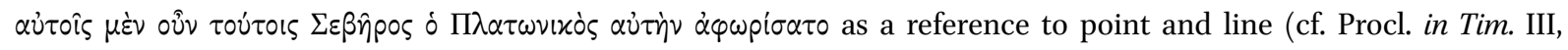
2.153.19-25), and contrasts this with Speusippus' use of three dimensions. On my reading, Iamblichus claims that Severus defines the soul "by means of these", i.e. of shape and extension, whereas Speusippus relates it to the form of the three-dimensionally extended, that is, to the borders (the surrounding surfaces) themselves. Iamblichus understands the term idea in Speusippus' definition correctly as the form determining the figure, that is, the limit determining what it encloses. There is doxographic evidence for the view that defines the soul as limit. This doctrine predates Philo of Alexandria, who at Somn. 1.30 cites the equation of intellect with limit as part of a doxographic list that is clearly based on a doxography on the essence of soul (Mansfeld (1990) 3070). We have no reason to believe that this description picks out Speusippus' doctrine of soul, but it is very well possible that it was part of the same intellectual debate.

${ }^{44}$ Like Xenocrates, Speusippus is reported to have written a treatise on the soul: DL 4.4; 4.13.

${ }^{45}$ Iambl. De an. ap. Stob. Ecl. I.49, p. 364.4-5 W. 'Everyway' means: in all three spatial dimensions. Cf. Ar. DC I.1, 268a613 . 
Timaeus against the criticism that the soul cannot be an extended quantity: ${ }^{46}$ the definition makes the point that soul is the form of extension, not unlike Aristotle's form. ${ }^{47}$ As a form it could indeed be considered to be indivisible. ${ }^{48}$ Ironically, this ties in with the interpretation of his philosophical opponents from the Tübingen School, according to which the idea is not that the soul is structured along three dimensions, but rather that it is the very principle of three-dimensionality. ${ }^{49} \mathrm{We}$ have encountered a similar idea in $D A$ I.2, 404b18-21 $(=\mathrm{T} 1, \mathrm{~b})$, a text that many scholars have taken to constitute evidence for Speusippus' teachings. Even though the definition is not clear about the soul being the source of dimensionality (or at least the proximate source of dimensionality in the physical world, if one thinks the first principles of the three dimensions are to be found at a higher level, as $D A$ I.2, 404b18-21 could suggest), it would make sense of the fact that the soul is called the form (or 'rational structure') of three-dimensional extension. This also establishes the link with Tim. 35a and the interpretations reported by Aristotle: by combining form with extension Speusippus' definition indeed unites something indivisible with something divisible. If that is indeed the reasoning behind the definition, Speusippus would be closer to Xenocrates than one would think at first blush. Xenocrates and Speusippus both may have thought that the 'numbers' of the tetrad (including the monad, which only Speusippus considered to be a number) were associated with the point and the three spatial dimensions. ${ }^{50}$

The status to be attributed to the definition is, however, not uncontested.$^{51} \mathrm{H}$. Cherniss $\mathrm{5}^{52}$ is convinced that the definition does not correspond to a Speusippean theory, but is merely the latter's explanation of what is meant in the Timaeus and an attempt to defend Plato against Aristotle's critique. Speusippus could not possibly have held that the soul is geometric, since

\footnotetext{
${ }^{46}$ Ar. De an. I.3, 407a2-3.

${ }^{47}$ Cherniss (1962) 511. Cherniss moreover points out that Aristotle sometimes identifies the form (

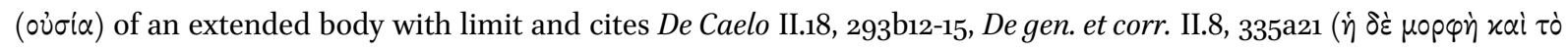

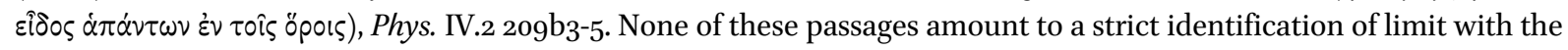
essential form, but they do establish a connection, which suffices for the reconstruction of an early Academic debate.

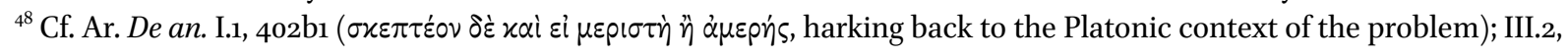
427a2-15.

${ }^{49}$ Moreover they see a perfect accord between this view, attested for Speusippus, and Plato's unwritten doctrines. Cf. Gaiser (1998) 22, 51, 347, n. 41; Krämer (1964) 33, n. 43; 209, n. 48.

${ }^{50}$ Pace Festugière (1990) 180, n. 2.

${ }^{51}$ Isnardi Parente (1980) 337-39 provides a survey of the debates regarding the authenticity of the definition. In $D e$ communi mathematica scientia 9, 40.7-41.3, Iamblichus merely quotes the definition without specifying its author.

${ }^{52}$ Cherniss (1962) 509-11.
} 
Aristotle attributes the view to him that the principles of magnitude are different from that of soul, the latter being inferior to mathematicals (Met. Z1, 1028b21-24). ${ }^{53}$ L. Tarán, supporting Cherniss, argues that Iamblichus mistook what was merely an interpretation of the Timaeus for Speusippus' own view. ${ }^{54}$ M. Isnardi Parente, on the contrary, is convinced that Iamblichus offers a trustworthy picture of the debates in the ancient Academy. She argues that there is no incompatibility with Aristotle's report (she claims T1, b-c for Speusippus) and that Speusippus fully endorsed the definition. ${ }^{55}$ In my view, the evidence suggests that Speusippus seriously entertained the account of the soul that corresponds to the definition attributed to him. There are no sufficient grounds to assume, with Cherniss and Tarán, that he was utterly non-committal toward the definition and the doctrine that follows from his interpretation of the Timaeus. That, however, does not mean we have to impute him with a strongly dogmatic and rigid account. His interpretation of the soul may rather have been an element in the debates that evolved among the followers of Plato.

\section{Eratosthenes}

A surprising presence in Proclus' doxographic list is Eratosthenes (in Tim. III, 2.152.21-30). The view Proclus attributes to him is remarkably close what Plutarch tells us about Crantor: ${ }^{56}$ Eratosthenes understands the soul's intermediary position ( $\dot{\varepsilon}^{\prime} \nu \mu \dot{\varepsilon} \sigma \omega$, Tim. 35a3) between the divisible and the indivisible as the soul having something corporeal and something incorporeal. From Proclus' testimony, it can be plausibly inferred that Eratosthenes identifies indivisible being with the intelligible and divisible being with body. ${ }^{57}$ Proclus objects that there can be no blend of the extended with the unextended or of the incorporeal with body (152.28-29 - I take this criticism as directed against both Eratosthenes and Severus, even though the ensuing phrase pertains to Severus alone). Moreover, he argues it is wrong to think that the soul can contain a bodily element (2.154.12-13), and that Eratosthenes therefore misconstrues what Plato means by an intermediate

\footnotetext{
${ }^{53}$ Met. Z2, 1028b21-24 = Speus. F29a Tarán.

${ }^{54}$ Tarán (1981) 365-71.

${ }^{55}$ Isnardi Parente (1980) 338-39. Finamore and Dillon (2002) 80-81, too, defend the authenticity of the definition.

${ }^{56}$ The similarity was already noticed by Hiller (1870) 71, and Solmsen (1942) 198.

${ }^{57}$ Proclus connects Eratosthenes' view with that of the (Middle) Platonist Severus, who is also quoted by Iamblichus. Both consider him as a representative of the mathematical interpretation of the soul. For Severus, see also Eus. Praep. $e v \cdot 13.17 \cdot 1-7$, where he is quoted as saying that the soul is a blend from impassible and passible substance. Boys-Stones (2018) 270-71 discusses the difficult issues raised by this passage.
} 
nature: according to Proclus, an intermediate nature does not contain the entities between which it is situated (2.151.12-30). This remark has a close parallel in Plutarch's criticism of Crantor. So Crantor and Eratosthenes are both accused, by different authors, but in similar terms, of having a materialist interpretation of Plato's account of the composition of the soul.

Some scholars have expressed doubt about the possibility that the Eratosthenes mentioned here could be the Hellenistic scientist and polymath, ${ }^{58}$ but as F. Solmsen shows these doubts are not justified.$^{59}$ Eratosthenes attended lectures by the Academic philosophers Arcesilaus and Apelles (which at least shows his interest in Platonism), concerned himself with the elucidation of mathematical, cosmological and anthropological aspects of the Timaeus, ${ }^{60}$ and wrote a work called Platonicus, ${ }^{61}$ a few fragments of which have been preserved by Theon of Smyrna. He is also cited, on a different issue (that the soul is always in some kind of body), in Iamblichus' De anima ${ }^{62}$ Since we know that he studied the three types of proportions used by Plato, ${ }^{63}$ one could even suspect that the information about these that Plutarch claims to have found in Eudorus (De an. procr. 1019e) goes ultimately back to the Hellenistic polymath. The example of Eratosthenes shows that the interest in the Platonic doctrine of the composition of the soul and in the interpretation of Tim. 35a did not all of a sudden end when the Early Academy was succeeded by the New. Eratosthenes was obviously interested in the interpretation of Plato proposed by Crantor, who was long dead by the time he arrived in Athens. ${ }^{64}$ We need not suppose that Eratosthenes considered himself a follower of Plato, but he certainly made efforts to advance our understand of his work. He may not have endorsed the Platonic concept of the soul, but he did offer an interpretation of it.

\footnotetext{
${ }^{58}$ Knaack (1907); Festugière (1990) 218, n. 1; Dodds (1963) 297, 317-18 (Dodds changed his mind as a result of Solmsen's article: see the addendum in the second edition, p. 348).

${ }^{59}$ Solmsen (1942) 202. Brisson (2000b) remains sceptical.

${ }^{60}$ See Aet. I.21.3, DG 318a6-7, b8-9, on Tim. 38C2-6; Iambl. DA ap. Stob. 1.378.1-18 W. = F26 Finamore-Dillon / Martone, on Tim. 42a3-4.

${ }^{61} \operatorname{Hiller}(1870)$.

${ }^{62}$ Iambl. $D A$ ap. Stob. 1.378.6-7 Wachsmuth.

${ }^{63}$ Solmsen (1942) 197 .

${ }^{64}$ Eratosthenes was probably born ca. 276/5 and died ca. 195. He arrived in Athens in the middle of the third Century. Arcesilaus became head of the Academy shortly after 276/5, the probable year of death of Crantor. He was the successor of Crates, who was the successor of Polemo, who died in 270/269. Cf. Dorandi (1992) 3777, 3779; Dorandi (1994) 328; Fuentes González (2000) 190-93. Krämer (2004) 114 includes Eratosthenes in the Old Academy, which from the point of view of chronology is bizarre. This categorisation testifies to an unease or even unwillingness to accept the existence of doctrinal Platonism in the age of the sceptic Academy.
} 


\section{Posidonius and Posidonians}

Posidonius deserves a place in the history of early interpretations of Tim. 35a because he adopted and expanded the Speusippean definition in light of the Timaeus and its exegesis. With what intention he did so, is a difficult question. We know that Posidonius was interested in Plato's work and made frequent use of it..$^{65}$ The account of the soul Plutarch attributes to him and his followers ${ }^{66}$ is, just as the other views we have discussed, based on a reading of Tim. 35a and Posidonius appears to have been aware of the connection with this passage. But let us first examine the evidence. Plutarch, who does not mention Speusippus' account, quotes the Posidonian definition. The context of Plutarch's treatise shows that this definition, too, is in the end the result of an exegetical engagement with Tim. 35a. This is also what Plutarch's testimony amounts to: it tells us about an interpretation of the Timaeus and a definition resulting from that interpretation. Plutarch's testimony alone will not allow us to infer that Posidonius would also be willing to make this definition his own. I shall, provisionally, take Plutarch to be discussing Posidonius' understanding of the Platonic concept of the soul, that is, the conception of Plato and his followers according to Posidonius.

Soul is according to Posidonius and his circle the form of what is everyway extended, constituted

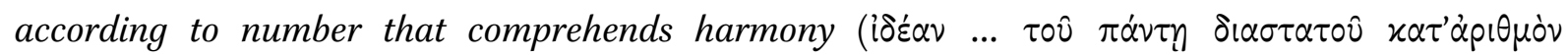

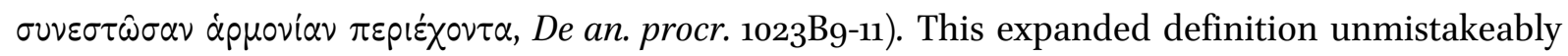
includes further ideas from the Timaeus. Plutarch introduces the the Posidonian account in the course of his criticism of the materialism, or rather the corporealism, of Crantor and possibly others. Due to a lacuna at $1022 \mathrm{E}$, we cannot establish the exact context. After the lacuna, Plutarch is discussing the meaning of the expression 'indivisible' and 'divisible being'. He explains that the

\footnotetext{
${ }^{65}$ Tieleman (2003) 208, n. 33, Bonazzi (2012) 315, n. 22, and Ju (2012) 96-97 give short surveys of the evidence.

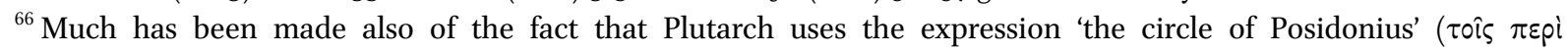

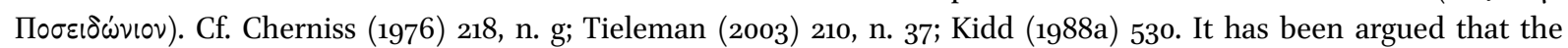
expression could denote either Posidonius, or Posidonius and his followers, or even just his followers. In my view the expression oi $\pi \varepsilon p$ í means 'those around $\mathrm{X}$ ', but conventionally it can be used to refer also just to $\mathrm{X}$ or to 'X and his circle.' The use of the expression by itself certainly does not allow us to exclude either X or the circle of X. Plutarch uses

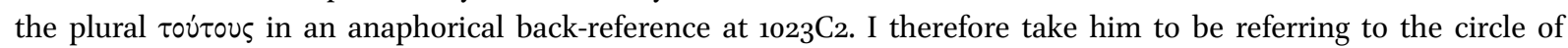
Posidonius, without this entailing that the views discussed are not those of Posidonius himself. What is more, even if he were referring exclusively to Posidonius' followers, it is clear that they would only be cited because the interpretation they defended was in line with that of their teacher. Hence I allow myself sometimes to use the name of Posidonius instead of the cumbersome 'Posidonius and his circle'.
} 
latter may be called matter in the sense 'substrate', as long as one does not hold it to be 'corporeal matter' (1022F3-6), i.e. the matter of ordinary, material bodies. Then he turns to those authors who interpret the composition of the soul in a corporealistic sense $\left(1022 \mathrm{~F}_{7}-1023 \mathrm{~A} 1\right)$. One of the arguments is, even in its wording, strongly reminiscent of an argument levelled earlier (1013B9-C4) at Crantor: "In what respect will the generation of the soul differ from that of the universe if both are composed of matter and the intelligible?" (1023A6-9). Plato had no materialistic conception of the soul, so Plutarch argues. For the master treats soul and material body as two different things and puts the latter inside the former (Tim. 34a3-4 and 36dg-e3). Moreover, Plato describes the composition of the soul well before he introduces matter (namely, soul at $35^{\mathrm{a}}$, and 'matter' in the passage on the receptacle ${ }^{67}$ at $\left.48 \mathrm{e} 2-49 \mathrm{a} 6\right)$. The sequence of the narrated creation story is of course very significant for everyone who agrees with Plutarch that it reflects the chronology of events at the beginning of the world.

After these remarks, which can be understood as being directed at a position that had already been introduced, namely that of Crantor, Plutarch extends his criticism to another interpretation, namely that of Posidonius and his followers:

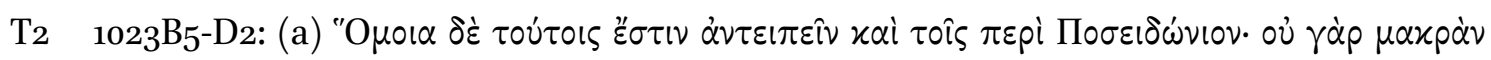

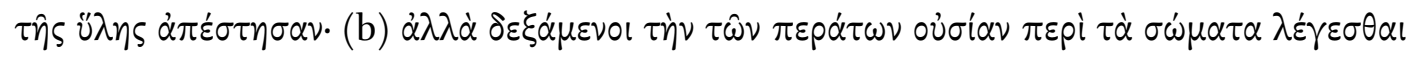

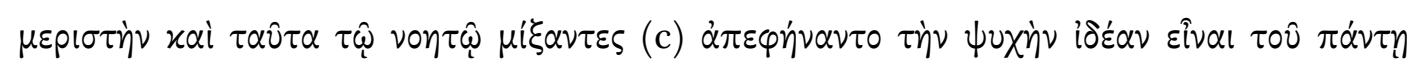

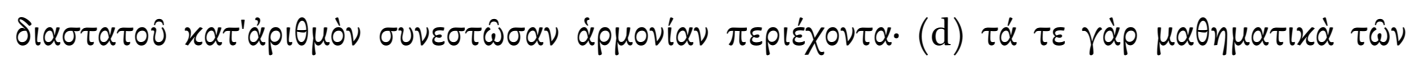

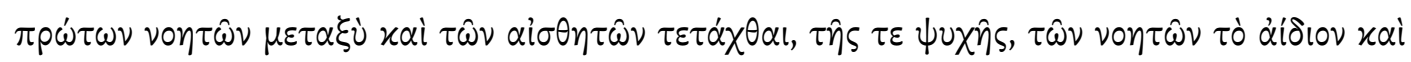

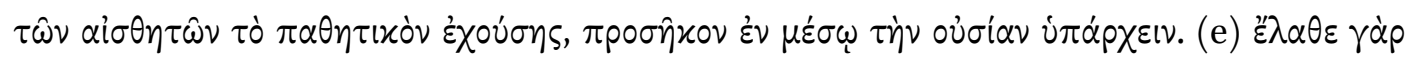

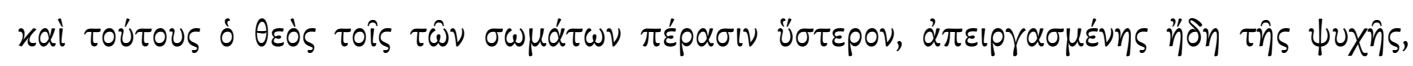

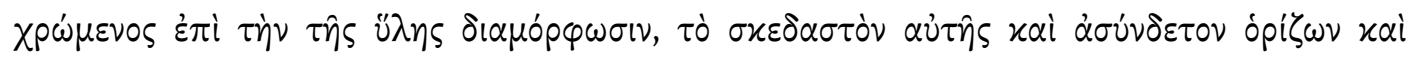

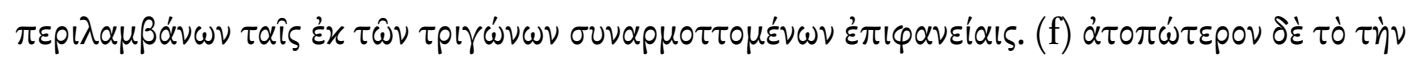

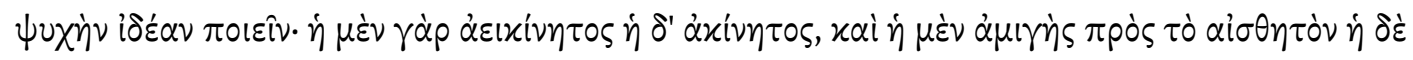

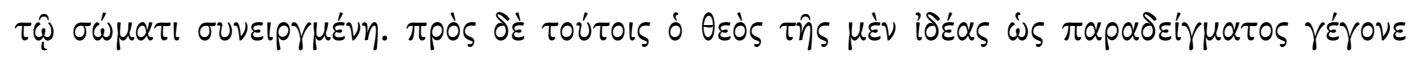

\footnotetext{
${ }^{67}$ See De an procr. $1023 \mathrm{~A}_{5}-8$ for the identification of the receptacle with matter.
} 


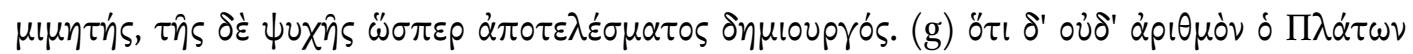

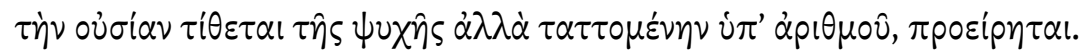

(a) We can make similar objections to Posidonius cum suis. Indeed, they did not observe a great distance from matter, (b) but rather, having taken 'the divisible around bodies' to mean the being of the limits and having blended these limits with the intelligible, (c) they declared the soul to be the form of what is everyway extended, constituted according to number that comprehends harmony. (d) This is based on the idea that the mathematicals are situated between the primary intelligibles and the sense-perceptibles and that it is appropriate that the soul, which possesses the everlastingness of intelligibles and the passivity of sense-perceptibles, has its being in the middle. (e) For these people, too, failed to notice that god uses the limits of bodies only at a later stage, when he had already completed the production of the soul: by means of them he provides internal structure to matter, by demarcating and enclosing its dispersiveness and unboundedness with the surfaces made of the triangles fitted together. (f) It is even more absurd, however, to make the soul a Form: for soul is always in motion, but Form is immobile; Form does not mix with the sense-perceptible, but soul is conjoined with the body; in addition, god's relation to Form has become that of the imitator of a paradigm, whereas his relation to soul has become like that of artisan to finished product. (g) And that Plato does not make number the being of soul, but rather presents the soul as being ordered by number: that we have explained earlier.

Plutarch expounds Posidonius' interpretation in sections (b-d). From (b) we learn that Posidonius engaged with Tim. $35^{\mathrm{a}^{68}}$ and that, on Plutarch's understanding, he identified the ingredients divisible and indivisible being with the being of the limits and the intelligible, respectively. Posidonius took the 'divisible being around bodies' clearly quite literally as meaning the surfaces,

\footnotetext{
${ }^{68}$ Kidd (1988a) 531: "This shows that Plutarch at least believed that the definition of soul which follows arose in the context of interpretation of the Timaeus. It does not follow that it occurred in a Commentary on the Timaeus (see F85). Nor is there evidence to show that it did not."
} 
that is, the limits, surrounding the bodies. ${ }^{69}$ One wonders how could Plutarch justify his charge of materialism by pointing to the fact that Posidonius composed the soul out of the intelligible and limits? ${ }^{70}$ Plutarch certainly knew that limits for Stoics are incorporeal. ${ }^{71} \mathrm{I}$ see two possible explanations. The identification of limits with the kind of being that becomes ${ }^{72}$ divisible in the presence of bodies $\left({ }_{1023} \mathrm{~B}_{7}-8\right)$ brings them in close vicinity with bodies and may even suggest they are properties of bodies. Being thus called, they seem to be affected by bodies. Regardless of what he thinks the ontological status of limits is, Posidonius in his reading of Tim. $35^{\text {a }}$ has taken an entity that is intimately bound up with matter to construct the soul. This is not to put a material ingredient into the soul, but rather something belonging to matter. ${ }^{73}$ This would explain why Plutarch says that Posidonius and his followers do not stray far from matter. An alternative explanation would be that Plutarch is aware of Posidonius' claim ${ }^{74}$ that surfaces, being twodimensional limits of bodies, ${ }^{75}$ have real existence, taking this to mean that they are corporeal. ${ }^{76} \mathrm{I}$ tend to the first explanation, because it does not need to appeal to doctrines that Posidonius would endorse.

Posidonius' justification of his definition (d) appeals to the intermediate position, between Forms and sense-perceptibles, occupied by the mathematicals and by the soul. Plato explicitly construes the soul in the middle between divisible and indivisible being, which lends support to the mathematical interpretation of the Platonic soul adopted by Posidonius. This mathematical interpretation was not just suggested to Posidonius by Timaeus' account of the harmonical divisions of the world soul, but also, and more importantly, by the interpretation(s) of Speusippus

\footnotetext{
${ }^{69}$ The fact that Plato uses the word ousia moreover fits nicely with Posidonius' view that surfaces have real existence. See below, p. 22.

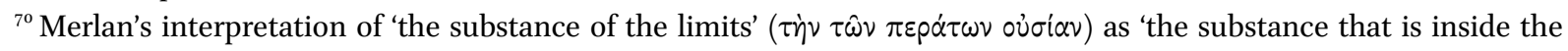
limits', i.e. the substance that is bounded by limits, in other words, matter, fails to convince. Cf. Merlan (1968) 37-38; Thévenaz (1938a) 65; Cherniss (1976) 218-19; Kidd (1988a) 531.

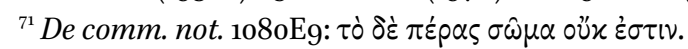

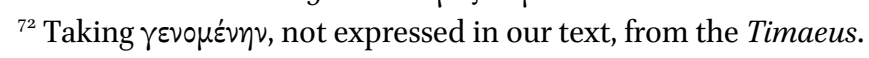

${ }^{73} \mathrm{Ju}(2012)$ 101-2, has a similar interpretation of Plutarch's view of Posidonian limits.

${ }^{74}$ DL 7.135 = Pos. F16 Edelstein/Kidd.

${ }^{75}$ Posidonius defines 'surface' as 'the limit of body, or that which has length and breadth only, but not depth': Pos. F16 Edelstein/Kidd $=$ DL 7.135.

${ }^{76}$ This is the interpretation offered by Cherniss (1976) 218-19. Kidd (1988a) 532, interprets the passage along the same lines. See also Reydams - Schils (1997) 466-67. Posidonius moreover claimed that anything that has real existence differs only notionally from matter: Pos. F92 Edelstein/Kidd (Ar. Did. Epit. fr. phys. 20, DG 458.10-11).
} 
and possibly other Early Academics (see T1, b-c). The reference to primary intelligibles, ${ }^{77}$ that is Platonic Forms, and to mathematicals as, implicitly, secondary intelligibles occupying an intermediate position between the Forms and the sense-perceptibles, ${ }^{78}$ is a clear indication that Posidonius in the first instance offers an exegesis from within Plato's, and not his own, metaphysical framework, even though in (b) Plutarch presents the Posidonian definition as that

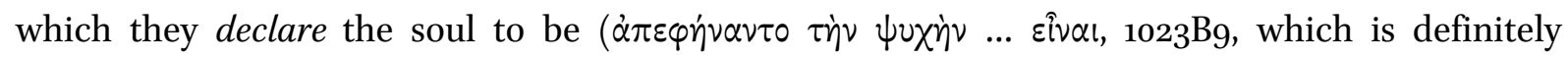
different from stating "they declared the Platonic soul to be"). This is not to say that Posidonius could not also, in a second gesture, endorse certain elements of his interpretation for his own understanding of the soul. I shall later argue that that is indeed what he will do.

At 1014D9-10 Plutarch had already remarked that it would be misguided to understand 'divisible being' as some kind of quantity, whether discrete or continuous, because pluralities of unities or points, lengths and breadths are properly said of bodies, not of souls. This does not just confirm my hunch that limits are too close to bodies for them to be included in the soul, but moreover constitutes further evidence for my hypothesis that Plutarch was very much aware of the existence of interpretations that equate one or more components of the soul with numerical or geometrical entities. This is the type of interpretations to which also Aristotle alludes and that underlie Speusippus' definition of the soul, not cited by Plutarch but integrated in the Posidonian definition ${ }^{79}$ he does cite and discuss.

Posidonius' definition is not identical to Speusippus': to the Speusippean core he adds the phrase 'constituted according to number that comprehends harmony'. This is very much in the spirit of Tim. $35 \mathrm{~b}_{4}-36 \mathrm{~b} 5$. Posidonius' definition is sophisticated while it combines elements from the 'arithmetical' and 'geometrical' definitions, without making the soul into either an arithmetical or

\footnotetext{
${ }^{77}$ Like Plutarch here and at Quaest. Plat. III, 1001C11, Alcinous, too, calls the transcendent intelligible forms the first intelligibles (Did. VII, 162.15; IX, 163.14-17). Second intelligibles are for him the forms in matter (Did. IV, 155·39-42).

${ }^{78}$ The passivity of the sense-perceptible is a standard Platonic view. E.g. Plut. Quaest. Plat. III, 1002A8-10. Compare Ar. Met. A6, 987b14-18; Z2, 1028b19-21. In his account of Crantor's position, Plutarch calls the nature of bodies $\tau \dot{\eta} \nu \pi \varepsilon p i ~ \tau \dot{\alpha}$

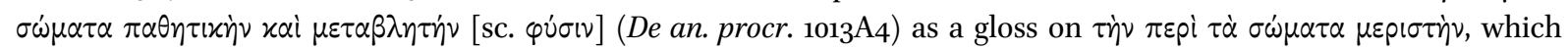
helps to explain $\tau \dot{0} \pi \alpha \theta \eta \tau$ iò $v$ in the present passage. The passivity of matter would also fit perfectly with the Stoic concept of the role of the passive principle. Cf. Tieleman (2003) 211-12.

${ }^{79}$ Thévenaz (1938b) 18, n. $5^{2}$ already mentioned the possibility that Posidonius drew inspiration for his definition from DA I.2.
} 
a geometric entity ${ }^{80}$ Indeed, according to the first, Speusippean segment of the definition, the soul is not defined simply as extension, but as the 'form' of extension; and in the second part the soul is not called number, but organised according to numerically expressible proportions. ${ }^{81}$ The question remains why Plutarch quotes Posidonius' definition without mentioning Speusippus. This could mean (1) either that Posidonius did not mention Speusippus by name and that Speusippus' definition was not familiar to Plutarch; (2) or that Speusippus was indeed not the author of the definition; (3) or simply that Plutarch did not think is was necessary to mention Speusippus in this context.

Plutarch is unlikely to be wrong, in (b), either about the fact that Posidonius connected his definition of the soul with Tim. 35 a or about the identity of the ingredient divisible being belonging to body'. But what could it mean for Posidonius that the latter is mixed with the intelligible, and hence that 'indivisible being' is the intelligible? Reading Posidonius' definition, Plutarch apparently understood 'form' (idea) to mean the rational structure, itself indivisible, of what is extended, whereas that which is extended are the two-dimensional limits envelopping three-dimensional bodies. That is why, in (f), he could criticise Posidonius for taking the word idea in the definition as equivalent to a Platonic Form, which would entail that the soul is a Form. As I shall argue shortly, Posidonius probably made use of the Timaeus in order to advance the view that the soul is, in its essence, structured according to mathematical principles and that our reasoning faculty, like that of the world soul, is able to grasp intelligible truths by means of number. It cannot be excluded that Posidonius thought that Plato, when talking about form (idea) at Tim. 35a, had in mind the intelligible, that is, the transcendent Form. That was at least Plutarch's understanding when he learned about the Posidonian definition and interpretation. ${ }^{82}$

\footnotetext{
${ }^{80}$ The reference to harmony adds a further science. For the relation between the definition and Posidonius' classification of sciences, see Toulouse (2005).

${ }^{81}$ This would certainly please Plutarch, as is obvious from his criticism of Xenocrates at 1013C6-D4. See also T2, g.

${ }^{82}$ Scholars unanimously regard Plutarch's criticism as misguided or disingenuous, as Posidonius' use of the term i $i \delta \varepsilon \alpha$ should in no way be taken as implying that he is talking about Platonic Forms: Untersteiner (1970) 32-33; Cherniss (1976) 219-20, n. c; Cherniss (1962) 510; Kidd (1988a) 537; Tieleman (2003) 211. The simplest explanation is that Posidonius is echoing Plato, who uses i $\delta \varepsilon \dot{\alpha} \alpha$ in a metaphysically innocuous way at 35a7. Reydams - Schils (1997) 468, plays with the idea that Plutarch may really have believed that Posidonius actually held that the active principle, here denoted by the term idea, is incorporeal. In a later doxography on the essence of soul, Macrobius in Somn. Scip. I.14, 19, states that Posidonius (F140) equated soul with form (Form?): "Posidonius [sc. dixit animam] idean." Cf. Kidd (1988a)
} 
I shall not go into the different points of criticism Plutarch formulates against Posidonius' interpretation. What is, however, interesting for our purpose, is the criticism levelled later at Xenocrates and Posidonius jointly (1023D4-7): limits and numbers offer no explanation for the soul's ability to cognise sense-perceptibles. They are more akin to the intelligible, so that their presence in the soul's composition helps to understand its higher cognitive faculty, which is directed toward the intelligible. ${ }^{8_{3}}$ This remark could be taken as evidence - admittedly weak evidence - for the possibility that Posidonius himself intended the Platonic definition of soul to account, among other things, for its cognitive powers. Taken together with the evidence provided by some passages from Sextus Empiricus, which I shall discuss below, the plausibility of this suspicion gets increased considerably: it is highly likely indeed that Posidonius wanted to attribute a cognitive function to the different constituents of the soul individuated in the Timaeus.

It is not easy to see how Posidonius' interpretation of Tim. 35a is to be seen in the light of his own Stoic views. Did he merely want to interpret Plato, or did he in addition want to use the results of his interpretation within his own philosophy? From Diogenes Laertius Life of Zeno we know that Posidonius espoused the classic Stoic view of the pneumatic nature of the soul: like Zeno and

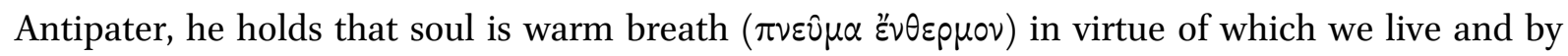
whose agency we move. ${ }^{84}$ But it is Diogenes Laertius' Life of Plato that offers more glimpses of Posidonius' engagement with Platonist doctrines of the soul. The whole passage on Plato's doctrine of the soul (3.67-69) has an undeniably Stoic flavour and considers several traces of Posidonius'

529: "In fact the doxography is evidence for nothing except that a doxographical tradition knew that Posidonius used the term i $\delta$ ć $\alpha$ in a definition of soul."

${ }^{83}$ See also Kidd (1988a) 537. For a different reading, see Tieleman (2003) 211, n. 39.

${ }^{84}$ DL 7.157 = Pos. F139 Edelstein/Kidd. 
interpretation and views. ${ }^{85}$ It is therefore likely that Diogenes used an intermediate source that integrated the Posidonian exegesis of the composition of the world soul. ${ }^{86}$

The definition of the soul here attributed to Plato states that soul is the form of breath extending

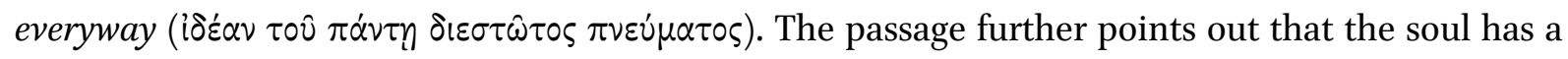

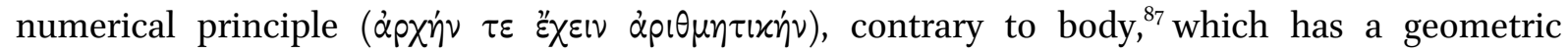
principle (3.67). The other attributes of the soul mentioned in this passage have more obvious parallels in Plato's dialogues, the Timaeus particularly, but the formula 'the form of pneuma extending everyway' instead combines two ideas that are elsewhere ascribed to Posidonius or to his interpretation of the Timaeus. ${ }^{88}$ The definition here quoted preserves the Speusippean core (cf. $\mathrm{T} 2, \mathrm{c}$ ) - the soul as form, and more particularly the form of something that is extended in all [three] dimensions - yet also introduces an element that is definitely not originally Platonic, but is linked to the Stoic view attested in the Life of Zeno that the soul consists of pneuma. To be more precise, however, the new definition does not state the soul is pneuma, but rather that it is the form of pneuma. Another element from the passage in Diogenes could be linked to Plutarch's account of the Posidonian interpretation of the Timaeus, namely the remark that the principle of the soul is numerical. This is possibly connected to the second part of the Posidonian definition in Plutarch, which states that the form in question is constituted according to number comprending harmony.

\footnotetext{
${ }^{85}$ The Posidonian provenance of the definition provided by Diogenes Laertius was already postulated by Schmekel (1892) 430. Untersteiner (1970) 33-35 posits a Posidonian influence for the entire doxography in DL (3.63-80a). Centrone (1987) 106-7 correctly observes that the contents of the doxography are heterogeneous, so that it is unlikely that the entire doxography derives from the same source. For my interpretation I merely need the definition to be of Posidonian origin, which most Posidonius scholars accept. The remark about the numerical principle of soul fits my interpretation and it would be nice if we could be certain of its Posidonian origin, but it is not strictly required for my purposes.

${ }^{86}$ Toulouse (2005) 156, n. 9 .

${ }^{87}$ Untersteiner (1970) 28 tries to construct the Greek in a different way, but his is not a natural reading of the Greek. See also Centrone (1987) 108.

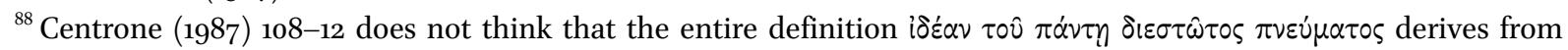
Posidonius, and resorts to the old hypothesis that $\pi \nu \varepsilon \dot{u} \mu \alpha \tau o \varsigma$ is a gloss. One of his arguments is that while Posidonius indeed considers the substance of the soul to be pneumatic, he does not call it a form (i $\delta^{\delta} \varepsilon$ ) of pneuma. This argument is not so strong, I think, because the whole point is that soul is the form of extended pneuma, i.e. of the extension of pneuma (in other words, the definition contains a hypallage). Centrone's second important argument consists in the claim that the position outlined here cannot be Posidonius' own. Even so, I would maintain that the passage is still consistent with Posidonius' interpretation of the Timaeus, especially if one understands his strategy along the lines suggested by T. Tieleman, namely that it was his intention to co-opt Plato for his own Stoic project. Kidd (1988a) 536, suggests that the 'definition' reported by Plutarch should be understood as a definition of the form of the soul, whereas 'fiery pneuma' is a description of its substance.
} 
The soul may itself be coextended with the body, but the principle that determines its internal organisation is numerical, presumably in accordance with its harmonic division described in Tim.

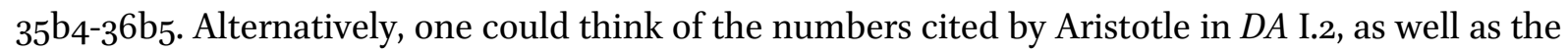
echoes of this passage in later texts. The Platonic definition of DL 3.67 at any rate agrees with the view going back to the early Academy that soul is the principle of spatiality, that is, of extension along three dimensions, bringing forth the extension of bodies. Whether it is itself extended is not clear from this passage (merely its principle is said to be numerical, not it itself).

Whether the soul according to this definition is itself pneumatic (probably not) and whether it is extended (unclear) is important in view of the question whether or to what extent Posidonius would be willing to endorse it as his own. It is rather unlikely that Posidonius would have given up the Stoic view that the soul is corporeal, and therefore extended in three dimensions ${ }^{89}$ But of course it would be misguided to treat the Stoicised Platonic definition from DL 3.67 straightforwardly as Posidonius' own. To be sure, it is very well possible he developed the Stoic expansion of the definition in the form it takes here, but it is equally possible that others used Posidonius' version of the Platonic definition, enriching it with a reference to the Stoic pneuma and embedding it in a Platonic context, adding extra Platonic features such as immortality, transmigration, self-motion, and tripartition. These others could very well have been Posidonians in some sense, but even then they need not belong to the same circle as the one to which Plutarch refers. As to Posidonius himself, we may presume that either he understood the Platonic definition as agreeing with the idea that the soul is extended, or he acknowledged that that is not the case without ever having had the intention to adopt any of the Platonic account of the soul as his own. I do not consider it very plausible, though, that he would have gone to such great lengths to study the Platonic conception of the soul, if their view had not been to some extent in line with his own interests. In my view, it is likely that certain aspects of the Platonic view had a genuine appeal for him. This would tie in with his usual strategy, for which there are several examples in other

\footnotetext{
${ }^{89}$ Tieleman (2003) 209-10 thinks that Posidonius indeed attempts to reconcile the Stoic and the Platonic account of the soul and uses Tim. 35a in order to argue that Plato too leans toward a materialistic concept of the soul.
} 
domains, of assimilating the ancients, in this case Plato, as thinkers who (imperfectly) anticipated the true Stoic doctrine..$^{90}$

This suspicion can be borne out by looking at the testimony provided by Sextus Empiricus, $A M$ 7.93-94. Sextus informs us that Posidonius, expounding the Timaeus, ${ }^{91}$ appeals to the principle that like is known by like in order to explain why one of our cognitive faculties, reason, the 'judge of all things', can be called 'number', the reason being that number is also 'the principle of the constitution of the universe.' Just before this passage $(A M 7.92)$ Sextus has related the Pythagorean view that criterial reason is connected with the mathematical sciences. Although this passage is not about the constitution of the soul, but about its defining power, reason, it allows us better to understand the claim that the principle of soul is numerical. Posidonius clearly thinks that the arithmetic character of reason, no doubt connected to the soul's very nature, explains its criterial power.

A.E. $\mathrm{Ju}^{92}$ profitably connects this passage to the epistemological division of Tim. $27 \mathrm{~d}-28$ a between 'intellection along with reason' and 'opinion along with reasonless perception,' by which being and becoming, respectively, are grasped $(\pi \varepsilon \rho \iota \eta \eta \pi \tau o ́ v)$. Posidonius, she claims, has endorsed Plato's idea of soul's intermediacy in virtue of which it is capable of grasping both the intelligible and the

\footnotetext{
${ }^{90}$ See Tieleman (2003) 225-26, 251. The same idea is already adumbrated in Reydams - Schils (1997) 469.

${ }^{91}$ The scholarly discussion over whether Posidonius wrote a proper commentary is, in my view, sterile. It depends on what one is prepared to call a commentary, but more importantly we do not know what literary form his efforts concerning the interpretation of the Timaeus took. All we know is that he was seriously engaged in exegesis: this largely suffices for our present purpose. In the past scholars were more than happy to regard Posidonius as the author of a commentary on the Timaeus. Cf. Schmekel (1892) 430-32; Altmann (1906); Norden (1913) 348; Rudberg (1918) 23940; De Falco (1922) 54, 56; Abel (1964). Nowadays they are reluctant to do so. Reinhardt (1921) 416-17, n. 4; Merlan (1934) 211-12; Untersteiner (1970) 16-18; Posidonius and Theiler (1982) II, 403-4; Burkert (1987); Kidd (1988a) 339-40; Dörrie and Baltes (1990) 332; Barnes (1991) 216; Frede (1999) 778; Runia (2001) 28, n. 59; Ju (2012) 100. Kidd (1988a) 531 and Reydams - Schils (1997) 455 pronounce a non liquet. Largely neglected by the philosophical community are the arguments of Lasserre (1991), who claims that PGen Inv. 203 contains a part of the commentary by Posidonius. Decleva Caizzi and Funghi (1998) come to the conclusion that this attribution remains uncertain. Pap. Oxyrh. 16og recto col. II

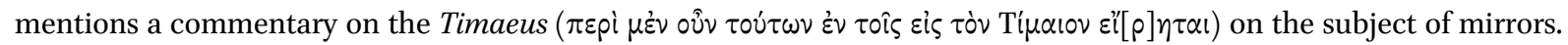
Diels originally attributed this commentary to Posidonius, but in DK ${ }^{6}$ I, p. 352.1-6 W. Kranz (1960) thinks that Eudorus is its author. Mazzarelli includes it in the fragments of Eudorus: Mazzarelli (1985), F33. According to the editors of CFP I.1** Anon (1992) 197, who quote Lasserre (1991), the identification with Eudorus has become untenable due to the discovery of a new fragment. Lasserre is in fact not so emphatic. He situates the commentary in the Middle Platonic period.

${ }^{92} \mathrm{Ju}(2012)$.
} 
sensible. ${ }^{93}$ Posidonius' particular contribution, according to Ju, is to mathematise reason. This not only appears from Plutarch's testimony, but also from an interesting parallel at Sext. Emp. $A M$ 7.119, a passage that contains striking echoes of $A M 7.93-94$ (the same list of cognitive faculties linked to their respective objects by the principle 'like is known by like'), and in addition claims that for Plato "soul becomes something incorporeal when it apprehends the incorporeal forms, such as those in numbers and those in the limits of bodies." Because of the strong similarities between the passages, it is safe to assume that Posidonius is behind this passage too, and is possibly even the source for the entire section $A M$ 7.89-140. Posidonius was clearly attracted to the Platonist mathematical interpretation of the soul, more particularly for the role it could play in explaining cognition of a reality pervaded by mathematical structures. This context may also allow us better to understand Plutarch's claim that Posidonius understands Plato as saying that the intelligible is blended with limit so as to produce soul. Posidonius was probably referring to number, which establishes a connection with the incorporeal and is at the same time a constituent or principle of soul. The remark quoted thus combines two of the constituents of Tim. 35a and links them to the cognitive power of the soul, based on the idea that like is known by like: in virtue of indivisible being, the reasoning aspect of the soul comprehends the arithmetic principles of the universe; in virtue of divisible being and as comprising the rational structure of bodily extension, it can grasp the limits of bodies.

Posidonius is said to have developed these ideas "while expounding the Timaeus" (

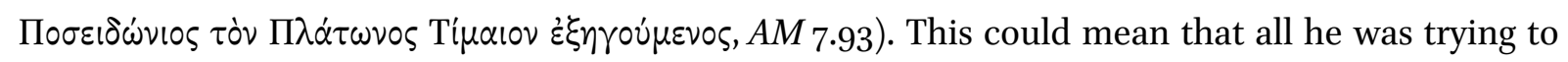
do was to shed some light on Plato's dialogue, but it could also imply that he was committing himself to a specific account of cognition, which he elaborated or supported with the help of the Timaeus. According to Ju, it was Posidonius' strategy to reclaim for his own thought the Pythagorean insight that mathematical reason is the ultimate principle of cognition, connected with the view that criterial reason in Plato involves mathematicals, as these belong to the realm of

\footnotetext{
${ }^{93} \mathrm{Ju}$ (2012) 110. Ju moreover draws a parallel with Antiochus, who uses the same passage to claim that reason is Plato's criterion. This argument rests on the hypothesis that the source for the $A M$ 7.141, is indeed Antiochus. This is highly speculative, but even if Antiochus is not behind this text, the existence of some Platonic tradition that claims reason is Plato's criterion is beyond doubt.
} 
intelligible Forms ${ }^{94}$ From this Ju draws the broader conclusion that it was not Posidonius' intention to set up Plato as a figure of the highest authority, but rather to claim "Pythagorean heritage as part of Stoicism's ancestry. ${ }^{m 5}$ While this may be basically correct as far as figures of authority go, the resulting picture is slightly misleading in that it remains silent about the fact that the Pythagorean tradition on which Posidonius could draw ${ }^{96}$ regarded Plato, and especially the Timaeus, as part of their own tradition. If Posidonius indeed set up Pythagoras rather than Plato as a figure of authority, he probably did so while using texts in which these two traditions were already inextricably blended. For the Pythagoreanising tendencies within Platonism originated already in the Early Academy and in some of Plato's own works and left their traces in Hellenistic and Posthellenistic sources.

Explaining cognition, however, was not the only reason for which Posidonius was attracted to an Early Academic definition of the soul. A fragment from Achilles' commentary on Aratus (Intr. in Ar. $13=$ Pos. F149, partim) shows that Posidonius also sets great store by the idea that the soul "holds

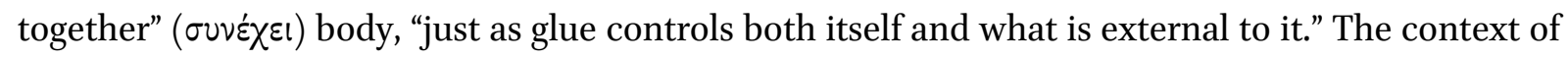
the fragment is anti-Epicurean, but as also I.G: Kidd suggests, Posidonius "may have shown particular interest in the soul as the containing concept. ${ }^{\prime 97}$ Another fragment, preserved in Proclus' Commentary on Euclid, corroborates this idea: figure $(\sigma \times \hat{\eta} \mu \alpha)$, understood as the enveloping limit, is not quantity, but the cause that determines, limits and contains. ${ }^{98}$ Proclus contradistinguishes Posidonius' view from Euclid's, insofar the latter includes in figure the quantity of what is encompassed by the limits, whereas Posidonius restricts it to the outside boundaries. It will not have eluded Posidonius that the definition of the soul as the form of what is extended in all

\footnotetext{
${ }^{94} \mathrm{Ju}(2012) 115^{-16 .}$

${ }^{95} \mathrm{Ju}(2012)$ 96-97.

${ }^{96}$ This is not to say that every Stoic contact with Pythagoreanism was of this nature. Brad Inwood suggested to me the example of Zeno, who was no friend of Plato or Platonism, but was the author of work with the title Pythagorean

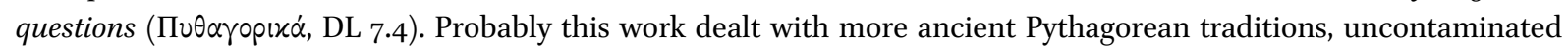
by Platonism; possibly the work contained criticism of the Pythagoreans. Cf. Gourinat (2018) 387 .

${ }^{97}$ Kidd (1988a) 550

${ }^{98}$ Procl. in Eucl. 143.8-11 = Pos. F196. As Kidd (1988b) 706-7 explains, this is an unorthodox view, as Chrysippus would include both what is contained and the container. For Posidonius' view of two-dimensional surfaces as limiting bodies, see Rashed (2016), esp. p. 335-337.
} 
directions can be understood as amounting to the idea that the soul provides ${ }^{99}$ the threedimensional extension in virtue of which bodies can exist. As we have seen, this is an idea implicit in $D A$ I.2 and in Speusippus' definition. Moreover, Plato was believed to have hinted at this role of the soul when he claims that the soul extends throughout the world and envelops it from the outside (Tim. 34b3-4; 36d8-37a2). Limit for Posidonius apparently combines the roles of containing or sustaining and delimiting. Presumably therefore Posidonius was attracted to the Platonic idea that the soul is the source of three-dimensional extension and thus plays a constitutive role for the existence and persistence of bodies as a way of understanding the synectic cause which body needs..$^{100}$ Since the soul has a causal role as glueing together body, for Posidonius it would have to be corporeal and hence extended. This is certainly connected to Posidonius' unorthodox claim that surfaces, that is, the two-dimensional limits of three-dimensional bodies, have real existence. ${ }^{101}$ We have seen that Posidonius understands Plato as saying that 'the being of limits' is one of the ingredients for the blending of the soul, and that in his definition soul is called the form of extension in all directions. The most plausible hypothesis therefore seems to be that he considers the combination of limiting surfaces, in virtue of being themselves determined by number (this very combination producing the soul), to deliver this form of three-dimensional extension without jeopardising the corporeality of soul, which is required for it to be a sustaining cause. As the comparison with glue shows, however, the containing cause cannot be identical with limit: the surfaces merely surround the body, whereas the containing cause (the pneuma) pervades it. But since the definition of soul does not claim identity between soul and limit, Posidonius could still adopt is, if he so wishes, without endangering its sustaining causal role.

Posidonius evidently engaged in exegesis of the Timaeus. As I have argued, he probably also used it for his own purposes. However, in coming to grips with the dialogue he undoubtedly made use of earlier interpretations, combining them or using a source in which several views were already

\footnotetext{
${ }^{99}$ As I have explained above, for Posidonius this could mean that it is merely the principle of the bodily dimensions, or that, also on Plato's view, the soul is itself three-dimensional.

${ }^{100}$ Pace Dörrie and Baltes (2002) 225; Ferrari and Baldi (2002) 278. For the Stoic notion of the synectic cause, see White (2003) 144-45.

${ }^{101}$ The question of the ontological status of limits in classical Stoicism is controversial. Some scholars regard them as incorporeals (which is also Plutarch's view: Comm. not. 1080E9-11), others as mere though-constructs, hence not even incorporeals. For useful surveys of various interpretations, see White (2003) $15^{0-51}$ and Rashed (2016) 337, n. 45.
} 
combined ${ }^{102} \mathrm{He}$ adopts a definition of the soul that is an expanded version of the definition elsewhere attributed to Speusippus; he relates this most clearly to the cognitive and ontological functions of the soul, but apparently also to its kinetic function (cf. DL 7.157); for its cognitive functions he appeals to the idea that like is known by like, and that the world is structured according to number - by the same numbers as are constitutive of the soul's composition - an idea which we also encountered in Aristotle's report of early interpretations and which was popular in Pythagoreanising circles. The combination of these ideas constitutes strong evidence for my hypothesis that Posidonius could rely on a source or sources providing information about some sort of tradition of exegesis of Tim. 35a (it cannot be excluded that he read Speusippus treatise on the soul and that this work was his only source for all of these ideas, but I consider this to be unlikely, since what our sources tell us about Speusippus' view of the soul is much more limited than what we have found for Posidonius). Whatever his intentions may have been, he certainly contributed to the development of Platonism, ${ }^{103}$ if only because Plutarch cites him as one of the many interpreters of the Timaeus and engages with his views. As to the problems his engagement with the Platonic definition of the soul could cause him in his own school, the most likely explanation is that he was able to present Plato as a precursor to Stoicism, which would allow him to retain some aspects while rejection others (such as the incorporeality of the soul).

\section{8. (Post)hellenistic Pythagoreans}

Iamblichus' survey of views on the essence of soul contains, as we have seen, references to Moderatus, the Pythagorean-Platonic contemporary of Plutarch, and Hippasos. The mention of Hippasus is interesting, because it probably leads us back to the pseudepigrapha of either the late Hellenistic or the early Roman period. The corpus of Pythagorean pseudepigrapha is relatively heterogeneous. Most texts probably date from the Early Imperial age ${ }^{104}$ but some other texts may predate what is commonly called Middle Platonism. ${ }^{105}$ The same Hippasus, whom Iamblichus

\footnotetext{
${ }^{102}$ He may have been acquainted with the view that equates the soul with limit. This doctrine, a variant of which is attested for Severus, predates Philo of Alexandria, as we have seen (supra, n. 43), although we cannot be sure that it had anything to do with the Timaeus.

${ }^{103}$ Merlan's idea is thus vindicated: cf. Merlan (1968) 34-58.

${ }^{104}$ See Ulacco (n.d.) 202-5.

${ }^{105}$ Pseudo-Ocellus, On the nature of the universe is an early example for the reception of the Timaeus. The text was cited in a doxographic source that was used by Varro (cf. Censorinus, De die natali 4.3), which means it cannot have been
} 
obviously took to be the ancient Pythagorean, is cited also in Iamblichus' commentary on Nicomachus, where he is reported as defining number as the "first paradigm of the creation of the world and also the measuring instrument of the god who creates" ${ }^{106}$ which ties in nicely with the testimony from Iamblichus' own De anima and with the Posidonian view found in Sextus Empiricus. That this information cannot go back to the Presocratic Hippasus is clear from the presence of Platonic concepts and ideas. Hence, we can safely assume that the information derives from a lost pseudepigraphic text. ${ }^{107}$ Pseudo-Hippasus apparently conceived of the paradigm of the Timaeus in arithmetic terms and possibly equated it with the world soul, or else conceived of the soul as embracing an image of the paradigm in virtue of which it could become a tool for the ordering of the world.

An extant text from the pseudo-Pythagorean tradition is pseudo-Timaeus Locrus, the purported source of Plato's Timaeus. He not only espouses the same non-literal reading of the Timaeus as Plutarch's opponents Crantor and Xenocrates, but also uses the same expression as Plutarch does in this respect: the world is generated 'in account (only)' ( $\lambda \gamma^{\prime} \omega_{\perp} \gamma \varepsilon v \varepsilon \dot{\sigma} \sigma \alpha \mathrm{l}$ TL 206.11-12; cf. Plut. De an. procr. 1013A9-10). He moreover (208.13-209.1) describes the same two-step mixture as we find with certainty in Plutarch, Xenocrates, and Crantor, and which was probably also at the basis of most other interpretations. ${ }^{108}$ What is more, Timaeus Locrus appears to share Plutarch's idea that

written later than than the third quarter of the first century BC. However, the text is probably older, since we have to allow some time between the date of its composition and its inclusion in a doxography and some more time between that and the consultation of this doxography by Varro. It is therefore more plausible that it dates from further back in the Hellenistic period. I intend to provide a fuller argument for this early dating elsewhere. For the doxographic contexxt, see Mansfeld (2002) 651, n. 557; Mansfeld and Runia (2010) 191.

${ }^{106}$ Iambl. in Nicom. arithm. 10.20-22. Compare Iambl. De an. 4 (Finamore-Dillon) / 7 (Martone), ap. Stob. Ecl. I.49, p.

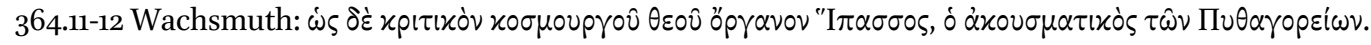

${ }^{107}$ See also, for more traces of this text, Thesleff (1965) 91-93.

${ }^{108}$ An exception is the Anonymus Klibansky (Apuleius?), 32.17-18 Stover: Deinde mundi animam ait esse concretam ex incorporali substantia quae sit inpartibilis, et [in] dividua et ex mixtura horum. For the constitution of the text, see Stover (2016) 179: even if individua was originally a marginal gloss, we would still need to have dividua or partibilis to account for horum and for the presence of divisible substance. Sameness and Difference are not mentioned, but the compiler has the mixture of the first two ingredients be itself the third ingredient for the second stage of the mixing process: Stage 1: divisible substance mixed with indivisible substance. Stage 2: divisible substance mixed with indivisible substance and the result of stage 1 (the same reading of the Timaeus passage is proposed by Taylor (1928) 109, 134). A possible explanation is that the author took Sameness and Difference to be alternative descriptions of Indivisible and Divisible Substance, in which case we would have a two-step mixing process comparable to, but not identical with, the one described in Plutarch and most of his sources. Cicero's translation (Tim. VII.21), too, differs from the two-step mixture process involving two steps and four ingredients: the mixture of indivisible and divisible being produce an intermediate entity that is composed of sameness and difference. What is striking is that he calls the indivisible, the 
'divisible being' derives from Difference (which Plutarch further derives from the Dyad). ${ }^{109}$ These and other ${ }^{110}$ parallels show that Timaeus Locrus and possibly an earlier exegetical tradition on which he relies can therefore be considered, in their exegetical activity, predecessors of Plutarch. Plutarch was certainly familiar with Pythagorean texts. He mentions some, without further specifications, in his treatise on the creation of the soul (De an. procr. 1028a4-5; $\mathrm{c} 2-3){ }^{.11}$

Philo of Alexandria is another author who was well-acquainted with the Pythagorean tradition, and more in particular also with doctrines of the soul like the ones we have examined here. He was an glutton for numerological speculation, and in several works connects the numbers of the tetractys with the unextended point followed by three dimensions. He calls these numbers the archetypes of the point and the dimensions (compare $\mathrm{T} 1, \mathrm{~b}-\mathrm{c}) .{ }^{112}$ That, however, is not all: he does so in the context of cosmogony, connects the numbers with the harmonic division of the heavens, as Plato does in the Timaeus (Philo substitutes the heavens for the world-soul), ${ }^{113}$ and states that the heavens have been created from indivisible and divisible substance. ${ }^{114}$ The ultimate sources for these speculations certainly have to do with the views reported by Aristotle, but Philo will certainly have used Pythagorean sources closer to his day. ${ }^{115}$

divisible, and the intermediate substance 'materia'. Also Calcidius' translation (p. 27.6-15) results in a different structure.

${ }^{109}$ Timaeus Locrus 206.3-4; compare Plut. De an. procr. 1024D9-11 and 1025 ${ }^{\mathrm{B}} 3^{-6}$.

${ }^{110}$ Like Crantor and Eudorus cited by Plutarch, but unlike Plutarch himself, Timaeus Locrus takes the number, 384 , as the basis for the calculations of the proportions of the soul (209.3-6). At 216.20-21 he makes the same remark about the closeness of the dodecahedron to the sphere as Plutarch does in Quaest. Plat. V, 1003C8-9. Plutarch's seventh Quaestio Platonica, on what Plutarch calls antiperistasis, is often closer to the wording of Timaeus Locrus than to that of the corresponding section in Plato's Timaeus. Timaeus Locrus' deviations from Plato can only be the result of an earlier exegetical engagement with Plato's text, whether by the same author or someone other. Some examples may suffice: compare Plat. Tim. 67b2-4 with Timaeus Locrus 220.4-5 and Plut. Quaest. Plat. VII, 1005B4-5 (the same Timaeus passage has inspired what is believed to be a Posidonian theory of consonance in Philo Quod deus sit immutabilis 84; it is combined with some Pythagorean-sounding speculation about the dyad); Plat. Tim. 79e10-80a4 and 8ob8-c3 with Timaeus Locrus 221.1-7 and Plut. Quaest. Plat. VII, 1004E11-1005 $\mathrm{A}_{3}$ and 1005B6-C20. A further close parallel can be noted between Timaeus Locrus 216.20-21 and Plut., Quaest. Plat. V, 1003C8-9. Similar observations about other pseudoPythagorean texts have been made by Ulacco (2017) $13^{-15}$.

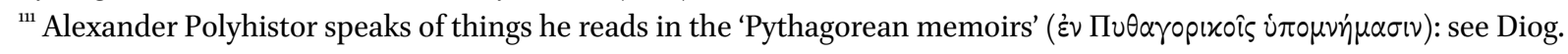
Laert. $8.25 ; 36$.

${ }^{12}$ De opif. mund. 47-49; De decalogo 26; De numeris 26; 26a; 97.

${ }^{113}$ De opif. mund. 48.

${ }^{114}$ De opif. mund. 103. Cf. De numeris $52 \mathrm{~d}$.

${ }^{115}$ For instance, he cites pseudo-Ocellus: De aet. mundi 12. 


\section{Coda}

We have been able to show that Plutarch's De animae procreatione is strongly indebted to an exegetical tradition that started in the Early Academy and continued in Hellenistic and PostHellenistic times. Platonic philosophers, and even one notorious figure from a rivalling school, were convinced that it was important to define the soul by studying its composition, such as Plato describes it in Timaeus 35a. Most of them understood the mixing process as a twofold process, consisting of a first blend of Divisible and Indivisible Being, to which Sameness and Otherness were added. What the names for the ingredients stood for, was a matter of controversy. As could be derived from Plato's account and also appears from Aristotle's discussion of it, most thought that the definition had to account for the cognitive, motive and ontological functions of the soul. The numbers of the tetractys, which figure prominently in Aristotle's account, were held to explain the ontological function of the soul as the source of spatial extension in three dimensions. I have added a table where the different positions are characterised from these points of view.

The list of thinkers and texts moreover shows that doctrinal Platonism was not extinct in the Hellenistic age. ${ }^{116}$ Presumably, thinkers attracted to Plato but not to Academic scepticism presented their views as Pythagorean. ${ }^{117}$ They were to some extent justified in doing so given the Pythagorean outlook of key parts of the Timaeus and by the Pythagorean aura exuded by the Early Academy.

\section{Bibliography}

Abel, K. (1964) 'Zu Poseidonios' schriftstellerischem Nachlaß', Rheinisches Museum für Philologie 107, 371-73

Altmann, G. (1906) De Posidonio Timaei Platonis commentatore (Berolini)

Anon (1992) Corpus dei papiri filosofici greci e latini (CPF). Testi e lessico nei papiri di cultura greca e latina Parte I: Autore noti, $1^{* *}$ (Firenze)

Barnes, J. (1991) 'The Hellenistic Platos', Apeiron 24, 115

Bonazzi, M. (2012) 'Antiochus and Platonism', in D.N. Sedley (ed.), The philosophy of Antiochus (Cambridge - New York) 307-33

\footnotetext{
${ }^{116}$ Older, Hellenistic, strata of the 'Aetian' doxography contain ample information about Plato's doctrines, and it is not uncommon to find these combined with 'Pythagorean' material. I have mentioned some examples in footnotes.

${ }^{117}$ It is not my intention to resuscitate the old idea of an esoteric tradition in the New Academy. Cf. Sext. Emp. PH 1.234; Aug. Contra Ac. 3.38. For a discussion of the ancient testimonies, see Krämer (1971) 55. It should be noted that Krämer himself rejects the idea of an esoteric tradition inside the Academy.
} 
Boys-Stones, G.R. (2018) Platonist philosophy 80 BC to AD 250: an introduction and collection of sources in translation (Cambridge)

Brisson, L. (2000a) Lectures de Platon (Histoire de la philosophie ) (Paris)

---- (200ob) 'Ératosthène', in R. Goulet (ed.), Dictionnaire des philosophes antiques III, d'Eccélos à Juvénal (Paris) 188

Burkert, W. (1987) 'Xenarchos statt Poseidonios: Zu Pap.Gen. inv. 203', Zeitschrift für Papyrologie und Epigraphik 67, 51-55

Centrone, B. (1987) 'Alcune osservazioni sui Placita di Platone in Diogene Laerzio III 67-80', Elenchos 8, 105-18

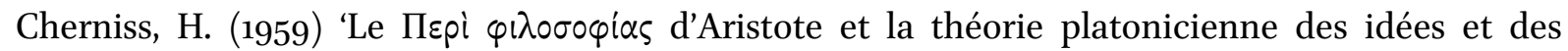
nombres (Book Review)', Gnomon 31, 36-51

---- (1962) Aristotle's Criticism of Plato and the Academy (New York)

---- (1976) Plutarch's Moralia in Seventeen Volumes 13,1, 999C-1032F (Loeb Classical Library ) (Cambridge, Massachusetts - London)

De Falco, V. (1922) 'Sui trattati aritmologici di Nicomacho ed Anatolio', Rivista Indo-Greca-Italica di filologia, lingua, antichità 6, 52-6o

Decleva Caizzi, F. and Funghi, M.S. (1998) 'Natura del cielo, astri, anima. Platonismo e aristotelismo in una nuova interpretazione di PGen inv. 203', in Papiri Filosofici. Miscellanea di Studi II II (Acccademia Toscana die Scienze e lettere 'La Colombaria', Studi 177 - Studi e testi per il Corpus dei Papiri Filosofici Greci e Latini, 9 ) (Firenze) 33-110

Dillon, J. (1993) Alcinous. The Handbook of Platonism (Oxford)

---- (2003) The Heirs of Plato. A Study of the Old Academy (347-274 BC) (Oxford)

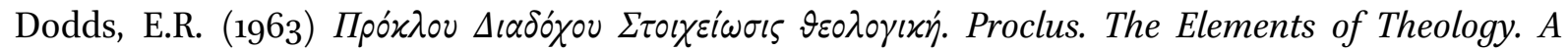
Revised Text with Translation, Introduction and Commentary (Second edition, ) (Oxford)

Dorandi, T. (1992) 'Il quarto libro delle "Vite" di Diogene Laerzio: l'Academia da Speusippo a Clitomaco', Aufstieg und Niedergang der römischen Welt II.36,5, 3761-92

---- (1994) 'Arcésilas de Pitane', in R. Goulet (ed.), Dictionnaire des philosophes antiques I (Paris) $326-30$

Dörrie, H. and Baltes, M. (1990) Der hellenistische Rahmen des kaiserzeitlichen Platonismus: Bausteine 36-72 (Der Platonismus in der Antike: Grundlagen, System, Entwicklung 2 ) (Stuttgart)

---- (2002) Die philosophische Lehre des Platonismus. Von der "Seele“ als der Ursache aller sinnvollen Abläufe. Bausteine 151-168: Text, Übersetzung, Kommentar (Der Platonismus in der Antike. Grundlagen - System - Entwicklung, Band 6.1) (Stuttgart - Bad Cannstatt)

Ferrari, F. and Baldi, L. (2002) Plutarco. La generazione dell'anima nel Timeo (Corpus Plutarchi Moralium, 37 ) (Napoli)

Festugière, A.-J. (1990) La révélation d'Hermes Trismégiste III, Les doctrines de l'âme suivi de Jamblique, Traité de l'âme, traduction et commentaire. Porphyre, De l'animation de l'embryon. IV, Le dieu inconnu et la gnose (deuxième édition, ) (Paris)

Finamore, J.F. and Dillon, J.M. (2002) Iamblichus, De anima. Text, translation, and commentary (Leiden - Boston - Köln)

Frede, M. (1999) 'Epilogue', in K. Algra, J. Barnes, J. Mansfeld and M. Schofield (eds), Cambridge History of Hellenistic Philosophy (Cambridge) 771-97

Fuentes González, P.P. (2000) 'Ératosthène de Cyrène', in R. Goulet (ed.), Dictionnaire des philosophes antiques III, d'Eccélos à Juvénal (Paris) 188-236 
Gaiser, K. (1998) Platons ungeschriebene Lehre. Studien zur systematischen und geschichtlichen Begründung der Wissenschaften in der Platonischen Schule (3., unveränd. Aufl., ) (Stuttgart)

Göransson, T. (1995) Albinus, Alcinous, Arius Didymus (Studia graeca et latina Gothoburgensia ) (Göteborg)

Gourinat, J.-B. (2018) 'Zénon de Citium', in R. Goulet (ed.), Dictionnaire des philosophes antiques VII, d'Ulpien à Zoticus (Paris) 364-93

Grube, G.M.A. (1932) 'The Composition of the World-Soul in Timaeus 35 A-B', Classical Philology 27, $80-82$

Helmer, J. (1937) Zu Plutarch's 'De animae procreatione in Timaeo'. Ein Beitrag zum Verständnis des Platon-Deuters Plutarch (Diss. inaug., ) (München - Würzburg)

Hiller, E. (1870) 'II. Der П $\lambda \alpha \tau \omega \nu$ เxós des Eratosthenes', Philologus 30, 60-72

Isnardi Parente, M. (1971) 'Per l'interpretazione di Aristotele, De An. 404 B 18 sgg.', in R.B. Palmer and R. Hamerton-Kelly (eds), Philomathes. Studies and Essays in the Humanities in Memory of Philip Merlan (The Hague) 146-70

---- (1980) Speusippo. Frammenti. Edizione, traduzione e commento. Precedono testimonianze sull'Academia scelte e ordinate da Marcello Gigante (Napoli)

Isnardi Parente, M. and Dorandi, T. (2012) Senocrate e Ermodoro. Testimonianze e frammenti. Edizione, traduzione e commento (Pisa)

Ju, A.E. (2012) 'Posidonius as historian of philosophy: an interpretation of Plutarch, de Animae Procreatione in Timaeo 22, 1023b-c', in M. Schofield (ed.), Aristotle, Plato and Pythagoreanism in the first century BC. New directions for philosophy (Cambridge) 95-117

Kidd, I.G. (1988a) Posidonius II. The commentary: (i) Testimonia and fragments 1-149 (Cambridge Classical Texts and Commentaries, 14A) (Cambridge)

---- (1988b) Posidonius II. The commentary: (ii) Fragments 150-293 (Cambridge Classical Texts and Commentaries, $14 \mathrm{~B})$ (Cambridge)

Knaack, G. (1907) 'Eratosthenes, (6)', RE VI.1, 389.24-30

Krämer, H.J. (1964) Der Ursprung der Geistmetaphysik. Untersuchungen zur Geschichte des Platonismus zwischen Platon und Plotin (Amsterdam)

---- (1971) Platonismus und hellenistische Philosophie (Berlin - New York)

---- (2004) 'Die Ältere Akademie', in H. Flashar (ed.), Die Philosophie der Antike Band 3, Ältere Akademie. Aristoteles. Peripatos (Grundriss der Geschichte der Philosophie begründet von Friedrich Ueberweg , 2., durchgesehene und erweiterte Auflage, ) (Basel) 1-165

---- (2014) Gesammelte Aufsätze zu PlatonMirbach, D. (ed.) (Beiträge zur Altertumskunde 321) (Berlin)

Lasserre, F. (1991) 'Anonyme, Commentaire de l'Alcibiade I de Platon', in F. Decleva Caizzi, M.S. Funghi, M. Gigante, F. Lasserre and A. Santoni (eds), Varia papyrologica (Studi e testi per il Corpus dei Papiri Filosofici Greci e Latini, 5 ) (Firenze) 7-23

Mansfeld, J. (1990) 'Doxography and Dialectic. The Sitz im Leben of the Placita', Aufstieg und Niedergang der römischen Welt II.36, 3167-3177??

---- (2002) 'Cosmic Distances: Aëtius 2. 31 Diels and Some Related Texts', in M. Canto-Sperber and P. Pellegrin (eds), Le style de la pensée. Recueil de textes en hommage à Jacques Brunschwig (Paris) $429-63$

---- (2016) 'Aristotle in the Aëtian Placita', in A. Falcon (ed.), Brill's companion to the reception of Aristotle in Antiquity (Leiden - Boston) 299-318 
Mansfeld, J. and Runia, D.T. (1997) Aëtiana. The method and intellectual context of a doxographer Volume one, The Sources (Philosophia antiqua, 73 ) (Leiden)

---- (2009) Aëtiana. The method and intellectual context of a doxographer Volume two, The compendium, Part one. Part two (Philosophia antiqua, 114 ) (Leiden - Boston)

---- (2010) Aëtiana. The method and intellectual context of a doxographer Volume three, Studies in the doxographical traditions of ancient philosophy (Philosophia antiqua, 118 ) (Leiden - Boston)

Martone, L.I. (2014) Giamblico. De anima. I frammenti, la dottrina (Grece, arabo, latino. Le vie del sapere, Studi, 3 ) (Pisa)

Mazzarelli, C. (1985) 'Raccolta e intepretazione delle testimonianze e dei frammenti del medioplatonico Eudoro di Alessandria', Rivista di filosofia neo-scolastica 77, 197-209, 535-55

Merlan, P. (1934) 'Beiträge zur Geschichte des antiken Platonismus, II, Poseidonios über die Weltseele in Platons Timaios', Philologus 89, 197-214

Merlan, P. (1968) From Platonism to Neoplatonism (Third edition, revised, ) (The Hague)

Norden, E. (1913) Agnostos Theos. Untersuchungen zur Formengeschichte religiöser Rede (Leipzig Berlin)

Opsomer, J. (2004) 'Plutarch's De animae procreatione in Timaeo: Manipulation or search for consistency?', in P. Adamson, H. Baltussen and M.W.F. Stone (eds), Philosophy, Science and Exegesis in Greek, Arabic and Latin Commentaries I (Bulletin of the Institute Of Classical Studies Supplement 83.1) (London) 137-62

Phillips, J. (2002) 'Plato's psychogonia in later Platonism', Classical Quarterly 52, 231-47

Posidonius and Theiler, W. (1982) Posidonius. Die Fragmente (Texte und Kommentare 10 ) (Berlin)

Rashed, M. (2016) 'Posidonius on matter, body, and surface', Archiv für Begriffsgeschichte Sonderheft 13, 323-44

Reinhardt, C. (1921) Poseidonios Beck'sche Verlagsbuchhandlung

Reydams-Schils, G. (1997) 'Posidonius and the "Timaeus": off to Rhodes and back to Plato?', The Classical Quarterly $47,455^{-76}$

Ross, D. (1961) Aristotle, De anima (Oxford)

Rudberg, G. (1918) Forschungen zu Poseidonios (Skrifter utgivna av kungl. humanistiska vetenskapssamfundet i Uppsala 20,3 ) (Uppsala)

Runia, D.T. (2001) Philo of Alexandria. On the Creation of the Cosmos according to Moses. Introduction, Translation and Commentary (Philo of Alexandria Commentary Series, 1 ) (Leiden Boston - Köln)

Schmekel, A. (1892) Die Philosophie der mittleren Stoa in ihrem geschichtlichen Zusammenhange (Hildesheim)

Solmsen, F. (1942) 'Eratosthenes as Platonist and Poet', Transactions and Proceedings of the American Philological Association 73, 192-213

Stover, J.A. (ed.) (2016) A new work by Apuleius: the lost third book of the 'De Platone' (Oxford)

Tarán, L. (1981) Speusippus of Athens. A Critical Study with a Collection of the Related Texts and Commentary (Philosophia antiqua, 39 ) (Leiden)

Taylor, A.E. (1928) A commentary on Plato's Timaeus (Oxford)

Thesleff, H. (1965) The Pythagorean Texts of the Hellenistic Period (Acta Academiae Aboensis, Ser. A, Humaniora, 30, 1 ) (Åbo)

Thévenaz, P. (1938a) L'Âme du monde, le devenir et la matière chez Plutarque. Avec une traduction du traité "De la Genèse de l'Âme dans le Timée" (rre partie) (Collection d'Études anciennes) (Neuchâtel) 
----- (1938b) L'âme du monde: le devenir et la matière chez Plutarque avec une traduction du traité De la genèse de l'âme dans le Timée (rre partie) (Collection d'études anciennes ) (Paris)

Tieleman, T. (2003) Chrysippus' On affections. Reconstruction and interpretation (Philosophia antiqua, 94 ) (Leiden - Boston)

Toulouse, S. (2005) 'Les sciences et l'âme chez Posidonius. Remarques sur une définition de l'âme conservée dans Plutarque et sur le statut de l'astronomie et des mathématiques dans sa philosophie', in G. Romeyer Dherbey and J.-B. Gourinat (eds), Les Stoïciens (Bibliothèque d'histoire de la philosophie, nouvelle série ) (Paris) 153-72

Ulacco, A. (2017) Pseudopythagorica dorica: i trattati di argomento metafisico, logico ed epistemologico attribuiti ad Archita e a Brotino. Introduzione, traduzione, commento (Philosophie der Antike. Veröffentlichungen der Karl und Gertrud Abel-Stiftung 41) (Boston -Berlin)

'The appropriation of Aristotle in Ps-Pythagorean treatises', in A. Falcon (ed.), Brill's Companion to the Reception of Aristotle in Antiquity (Leiden) 202-17

Untersteiner, M. (1970) Posidonio nei placita di Platone secondo Diogene Laerzio III (Antichità classica e cristiana 7 ) (Brescia)

Viano, C. (1996) 'La doxographie du De anima (I, 2-5) ou le contre-modèle de l'âme', in G. Romeyer Dherbey and C. Viano (eds), Corps et âme. Sur le De anima d'Aristote (Bibliothèque d'histoire de la philosophie ) (Paris) 5 1-79 $^{-1}$

White, M.J. (2003) 'Stoic natural philosophy (physics and cosmology)', in B. Inwood (ed.), The Cambridge Companion to the Stoics (Cambridge) 124-52 